\title{
THE NORTH AMERICAN DRAGONFLIES (ODONATA) OF THE GENUS MACROMIA.
}

\author{
By Edward Bruce Williamson, \\ of Bluffton, Indiana.
}

All the North American dragonflies referred in the past to Macromia and Epophthalmia are congeneric and should be referred to Macromia. Didymops is very close to Macromia, and adequate venational characters for separating the two genera have not been detected. At the same time Didymops seems distinct enough by other characters, and the well-known North American species, transversa, is not discussed in this paper. I have seen only males of Azuma and Epophthalmia and of but one species of each. They are separated at once from Macromia, among other characters, by the greatly developed genital hamules in the male and by several venational characters, among which may be mentioned the abrupt apical curving of $\mathrm{M}_{3}$ and $\mathrm{M}_{4}$ in both front and hind wings, and the posterior widening of the hind wing from the anal angle to the termination of $\mathrm{M}_{4}$. (See figs. 1, 2.) Venational differences between Azuma and Epophthalmia are slight and are mainly to be found in the relations of $\mathrm{Cu}$ and $\mathrm{A}$ in the front wing proximal to the triangle. The crossed or uncrossed condition of triangles and subtriangles, which has been used in the past in distinguishing Macromia and Epophthalmia has no value here as a generic character.

The American species of Macromia are distributed generally over the United States and southern and eastern Canada. So far as I know, M. illinoiensis is the only species frequenting lakes as well as streams. The four species other than illinoiensis which I have seen in life prefer the larger streams, along which they course with swift flight at slight elevation, though they not infrequently leave the streams and pass out of sight over the tallest trees. They are most active during bright days, from about 9 or $10 \mathrm{a}$. m. till 3 or 4 p. m. At Sandusky, Ohio, where illinoiensis has been taken in large numbers, many collect toward evening in the cedars on Cedar Point, several individuals frequently choosing the same twig for a resting place. It is probable that during the day these indi- 
viduals seek insect food at a considerable elevation and hence escape observation. Mr. R. A. Muttkowski observed, at Milwaukee, several individuals of a species which he believed was not illinoiensis resting in close proximity to each other on a tree branch at a considerable elevation.

The height of the season for the species of Macromia seems to lie between the spring and autumn dragonfly seasons, when any possible competition with members of the same order would be at a minimum. Along the Wabash River during a hot day in early August odonate life seems almost suspended. It is on such a day that the collector may hope to find the largest number of individuals of this genus.

Macromias are reported to be eaten by birds. I have never observed examples of this myself. Once a pair in copulation (apparently pacifica) was repeatedly attacked by a kingbird, which

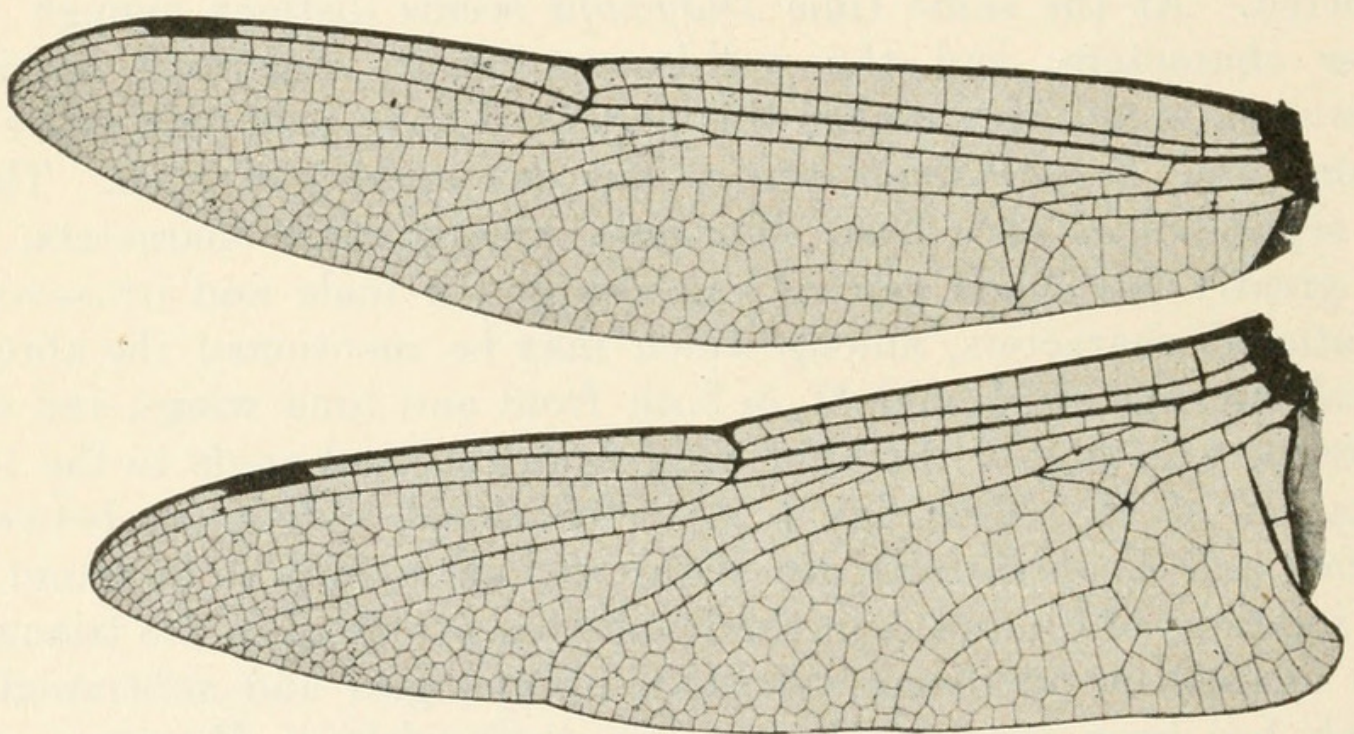

Fig. 1.-Wings of male Azuma elegans, From MiYazaki, Japan.

drove the dragonflies back and forth across the Wabash River several times, but the dragonflies eventually came to rest about 30 feet from the ground, clinging to the under side of an oak limb, and escaped without any damage. It is probable that any destruction by birds occurs during the teneral condition of the dragonflies. It is at this period, and only then, so far as I have observed, that kingbirds attempt to capture Anax junius. I have seen a yellow-billed cuckoo make repeated and unsuccessful attacks on an adult Epixschna heros. On the other hand, I once saw a catbird catch an adult Gomphus, but the bird pounced on the dragonfly just as it alighted on a clay bank, and did not take it on the wing.

No specimens of Macromia have been seen by me which were infested with the red mite which occurs so commonly on many dragonflies. In a large number of specimens examined, only two show abnormal wings which have resulted from apparent mechanical 
injury during their development. In these two cases the abnormality is slight and would interfere but little if at all with the normal functions of the insect.

The nymph of illinoiensis has been described by Cabot and Needham. I have collected neither nymphs nor exuviæ which have been specifically identified. In Steuben County, Indiana, I collected a few nymphs among tree rootlets in deep pools in a small woodland stream between two lakes, but I was unable to rear these. This paper deals only with imagoes.

Material for this paper has been collected during the past several years. In 1900 Mr. C. C. Deam collected a Macromia at Blount Springs, Alabama, which I was unable to identify. Since then I have had a revision of the North American Macromias in mind, and recently I have borrowed specimens from several sources. The result is that $I$ have before me a comparatively large number of

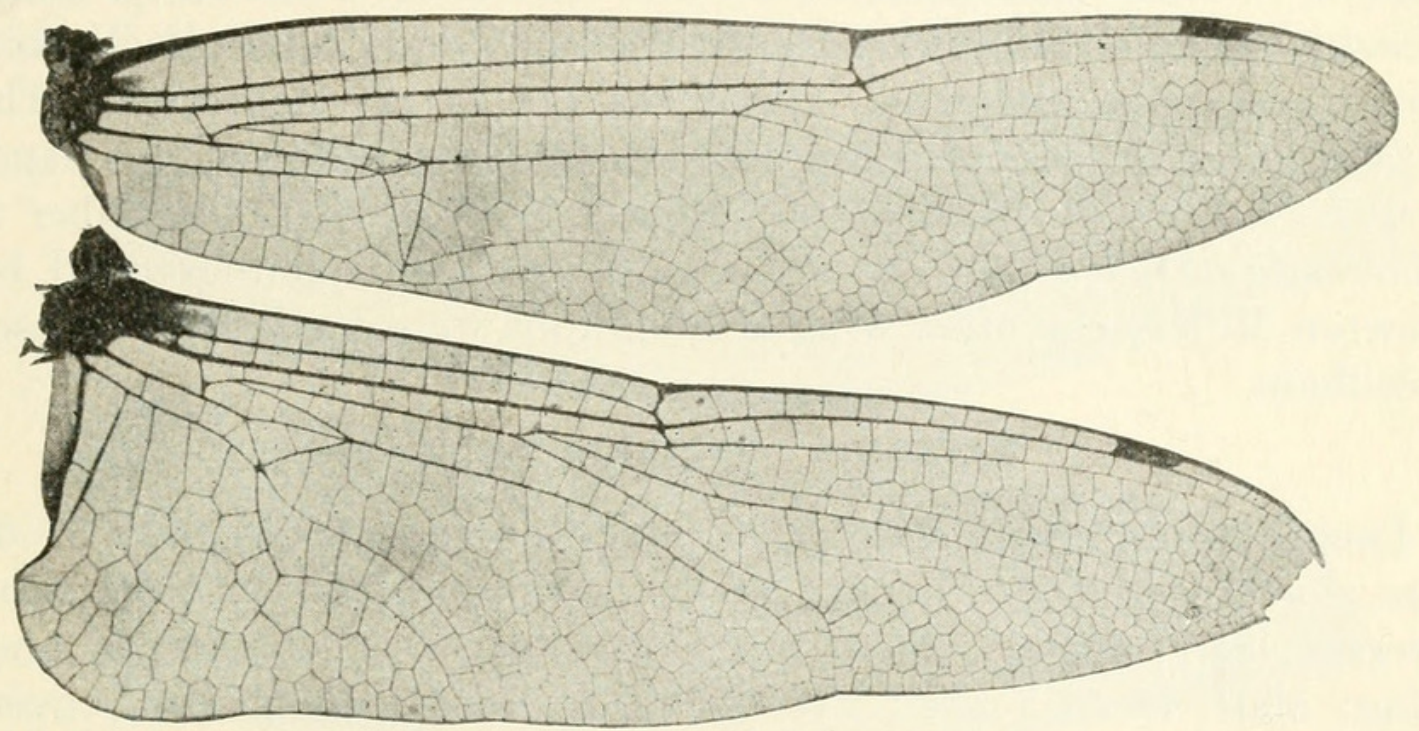

Fig, 2.-Wings of male Epophthalmia, species ? From Burma.

individuals. At the same time, the total number is not large and too few localities are represented. Macromias, with the exception of illinoiensis, are rare in collections. This is to be explained by their comparative rarity in nature, by their occurrence during a season when collectors are generally not actively engaged in field work, and by the difficulty of their capture because of their flight over deeper water and their swiftness. In life few insects rival them in beauty, power, and individuality. The few females taken, as compared with the number of males, is also an unfortunate factor which adds to the incompleteness of this paper.

In the following descriptions I have endeavored to indicate especially those characters which will aid in the recognition of the species as far as I am able to do so with the material before me. More formal and detailed descriptions at this time would, it seems to me, serve rather to confuse than emphasize the purpose of this paper. Since 
the purpose of this study was the preparation of a means of readily identifying specimens, repeated examination of the individuals before me has been disappointing in its failure to discover striking specific characters, and I have been tempted to return the borrowed material and not publish these notes at all. It is probable, however, that unless some new interest is taken by collectors in the North American Macromias the present difficulties will confront students of North American dragonflies for an indefinite period of time. In the hope of awakening some interest in these beautiful insects I find an excuse for the publication of this incomplete paper.

I am indebted to the following persons for the loan of material: Mr. C. C. Adams, Mr. C. S. Brimley, Dr. Philip P. Calvert (from his collection and the collection of the Academy of Natural Science, Philadelphia), Mr. Rolla P. Currie (collection U. S. National Museum), Mr. Samuel Henshaw (collection Museum of Comparative Zoology), Prof. J. S. Hine (collection Ohio State University), Mr. R. A. Muttkowski (collection Milwaukee Public Museum), and Prof. E. M. Walker. Unless otherwise indicated, specimens are in my collection. The total number of specimens examined in the preparation of this paper is $197-141$ males, 56 females. Nearly one-half of this number is Macromia illinoiensis. The wings of Azuma were photographed by Newton Miller; the other wing photographs were made by Professor Needham.

\section{MACROMIA TANIOLATA Rambur.}

Length of abdomen: Male, 56-61 mm.; average, 59; female, 57-61 mm.; average, 59.9. Length of front wing: Male, 50.5-56 mm.; average, 54.1; female, 56-61 mm.; average, 58.3. Length of hind wing: Male, 48-53.5 mm.; average, 52.1; female, 53-59 mm.; average, 55.6. Length of first tibia, male, $9 \mathrm{~mm}$; hind femur, male, 13 $\mathrm{mm}$. Length of tibial keel in length of tibia, male: First tibia, $\frac{3}{7}$; middle tibia, $\frac{1}{7}$ to $\frac{1}{4}$.

Antehumeral stripe present, extending about half or slightly less across the mesepisternum. Latero-ventral metathoracic carina brown, with or without a narrow yellow stripe anteriorly. Yellow ring on abdominal segment 2 narrowly interrupted dorsally (interruption not distinct in one male), not interrupted laterally. Costa dark colored.

Male.-Postclypeus clear greenish, labrum obscure dull yellow; dorsal spots on frons minute to $1 \mathrm{~mm}$. in diameter, lateral spots wanting or indistinct.

Abdominal spots on 3-6 small, rounded, separated dorsally, isolated laterally from any inferior pale areas, about equal in size on all the segments and occupying one-half or less the distance from the transverse carina to the base of the segment; on 7 the large quadrangular spot is separated by a narrow black ring from the base of the segment, 
and the yellow is produced very briefly posteriorly across the transverse carina in a small projection on either side of the middorsal line or as a small median squarish continuation; a short subbasal yellow ring on 8, narrowly or broadly interrupted dorsally, not reaching the lower edge of the segment on either side, and bounded posterioriy by the transverse carina (excepting in one male where it is produced dorsally a little beyond the transverse carina); ventrally the pale areas are generally indistinct, most definite on 2.

Wings hyaline, rarely with the faintest yellowish tinges over limited areas, and with the extreme apices faintly fumose; one specimen has the crossveins very narrowly edged with brown; no trace of costal or subcostal basal brown areas; stigma very dark reddish brown or black. (See fig. 3.)

Abdominal appendages ${ }^{a}$ distinctly different from illinoiensis, about $3.5 \mathrm{~mm}$. long (2.5 in illinoiensis), the apex more acute, and in profile more upturned, with the lower edge very slightly convex or straight subapically, and parallel with the upper edge, not converging as in

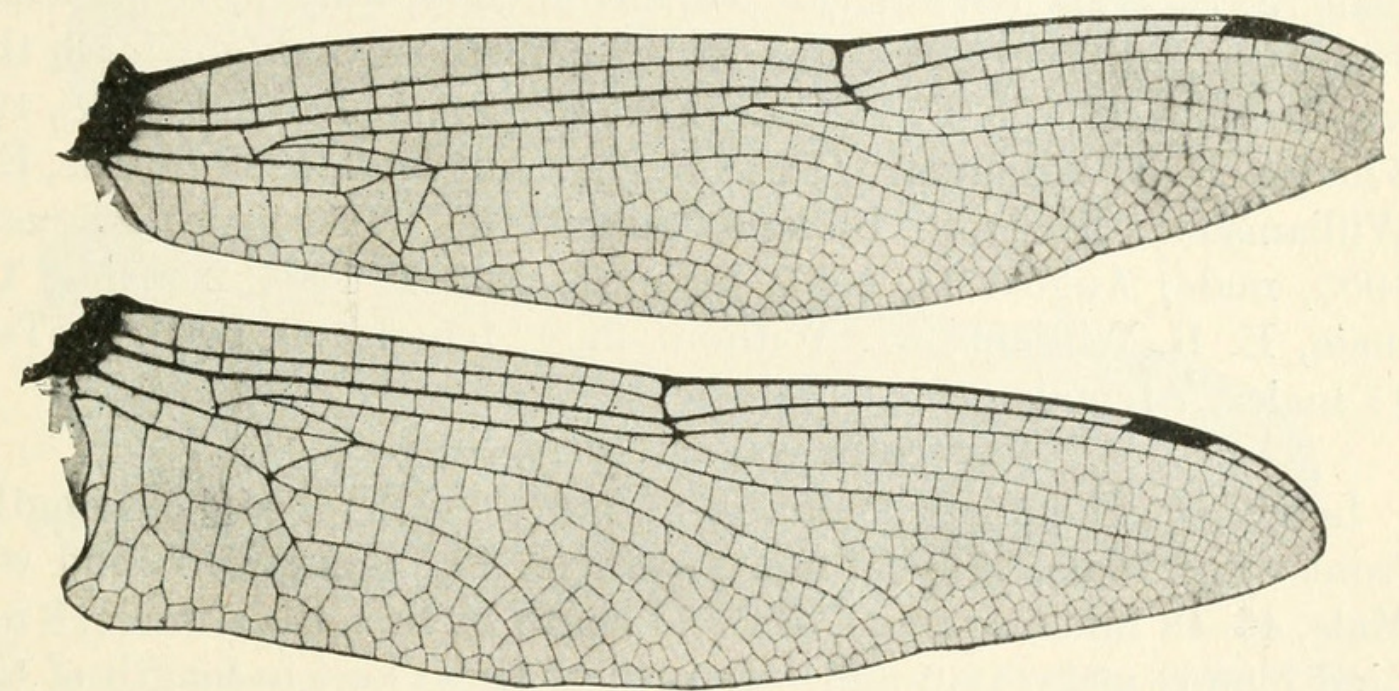

Fig. 3-Wings of male Macromia teniolata, Bluffton, Indiana, August 6, 1905.

illinoiensis; basal lateral external carina always present, but the tooth at its apical termination is always small and may be entirely wanting; a more or less distinct basal external pale area; inferior appendage of usual form, very slightly shorter than the superiors.

Female.-Similar to the male, but lateral spots on frons generally present, though less distinct than dorsal spots.

Abdominal spots similar, but spot on 7 may be divided or not in

$a$ Generally in the North American Macromias the appendages lack that strict uniformity of shape which is so marked a specific character in certain groups. The greatest variation in the shape of the superior appendages noticed by me is in the form of the apex. It would seem that this is due to the delicate nature of the appendages, especially probably during teneral life, when they may suffer mechanical injuries, or to post-mortem changes, since not infrequently the superior appendages of an individual are not symmetrical. Corduliinæ generally have the superior appendages weakly chitinized. 
the middorsal line (never divided in male), and the basal spots on 8 are reduced to a trace or, more usually, are wanting altogether.

Wings hyaline or tinged with yellowish, most strongly in a teneral specimen; in one or two cases the faintest trace of basal brown areas in the costal spaces; stigma yellow-brown to black, depending on age. The examination of the wings of 7 females shows the following: Triangle of front wing, free 2 , crossed 12 ; subtriangle of front wing and triangle of hind wing, crossed 14.

Vulvar lamina apparently a slight thickening of the median posterior edge of the sternum, with a slight folding into a shallow trough. Abdominal appendages as in illinoiensis.

This species can be confused only with the next. Differences are indicated in that description. It is the largest of our Macromias. For living colors see note under next species.

Material examined.-Rosslyn, Virginia, July 30, 1899, female, G. N. Collins (U.S.N.M.). Washington, District of Columbia, July 10, 1902, female, W. C. Weeden (U.S.N.M.). Toledo, Ohio, August 1, 1894, male, J. S. Hine (O. S. U.). Napoleon, Ohio, July 9, 1898, female, J. S. Hine. Elkhart, Indiana, May 31, 1896, teneral female, in thick woods, R. J. Weith (P. P. C.). Fort Wayne, Indiana, July 18, 1901, 5 males, E. B. Williamson (1 U.S.N.M.); August 3, 1902, female, E. B. Williamson. Bluffton, Indiana, August 6, 1905, male; August 8, 1905, male; August 11, 1907, male; August 1, 1908, 2 males, 1 female, E. B. Williamson. Without data, female (O. S. U.). Total, 11 males, 7 females.

\section{MACROMIA WABASHENSIS, new species.}

Length of abdomen: Male, 51-57 mm.; average, 54.4. Length of front wing: Male, 47.5-50 mm.; average, 49. Length of hind wing: Male, 46-48 mm.; average, 47.3. Length of first tibia, male, $8 \mathrm{~mm}$.; hind femur, male, $12.6 \mathrm{~mm}$. Length of tibial keel in length of tibia, male: First tibia, $\frac{3}{7}$; middle tibia, $\frac{1}{3}-$ to $\frac{1}{3} \cdot{ }^{a}$

Very similar to tæniolata, but may be recognized by the following characters: Costa (and antenodals and postnodals) yellow or yellowish as far as stigma or tip of wings; labrum less obscured, face paler and brighter colored; lateral spots on frons distinct (indistinct in two specimens); dorsal abdominal spot on 8 similar in shape and extent, relative to the transverse carina, to the spot on 7 (in two specimens a very narrow dorsal basal yellow ring on 9 ). (The spot on 8 , relative to the area of the segment, is really more extensive than on 7 , since on 7 there is a wider basal ring of black, though, compared with each other, the spot on 7 is larger than the spot on 8.)

Wings tinged with pale yellowish or hyaline (in about equal numbers), the extreme apex frequently slightly fumose; in 4 specimens a trace of brown spots in basal costal space. (See fig. 4.)

$a$ In one specimen, which otherwise seems to belong here, the tibial keel of middle tibia is $\frac{1}{5}$. 
Abdominal appendages similar to those of tæniolata, but seen in profile the apices of the superiors are less curved and upturned, the apical portion between the median external tooth and the apex less inflated, approaching the form of illinoiensis; median lateral external tooth present in every case.

From pacifica, which it resembles in color of costa, wabashensis is separated at a glance by the shorter antehumeral stripe, the smaller abdominal spots (on 3-6 scarcely one-third as large), and the obscurely colored ventral surface of the apical segments, especially of 8 . Differences in the appendages exist, but are scarcely definable.

From georgina it is separated at a glance by the obscure and scarcely evident ventral markings on 7 and 9 , which are isolated from the dorsal spots.

From both georgina and australensis it is separated by the brown latero-ventral metathoracic carina, and it lacks the distinct pale ventral basal areas on 8 and 9 of australensis.

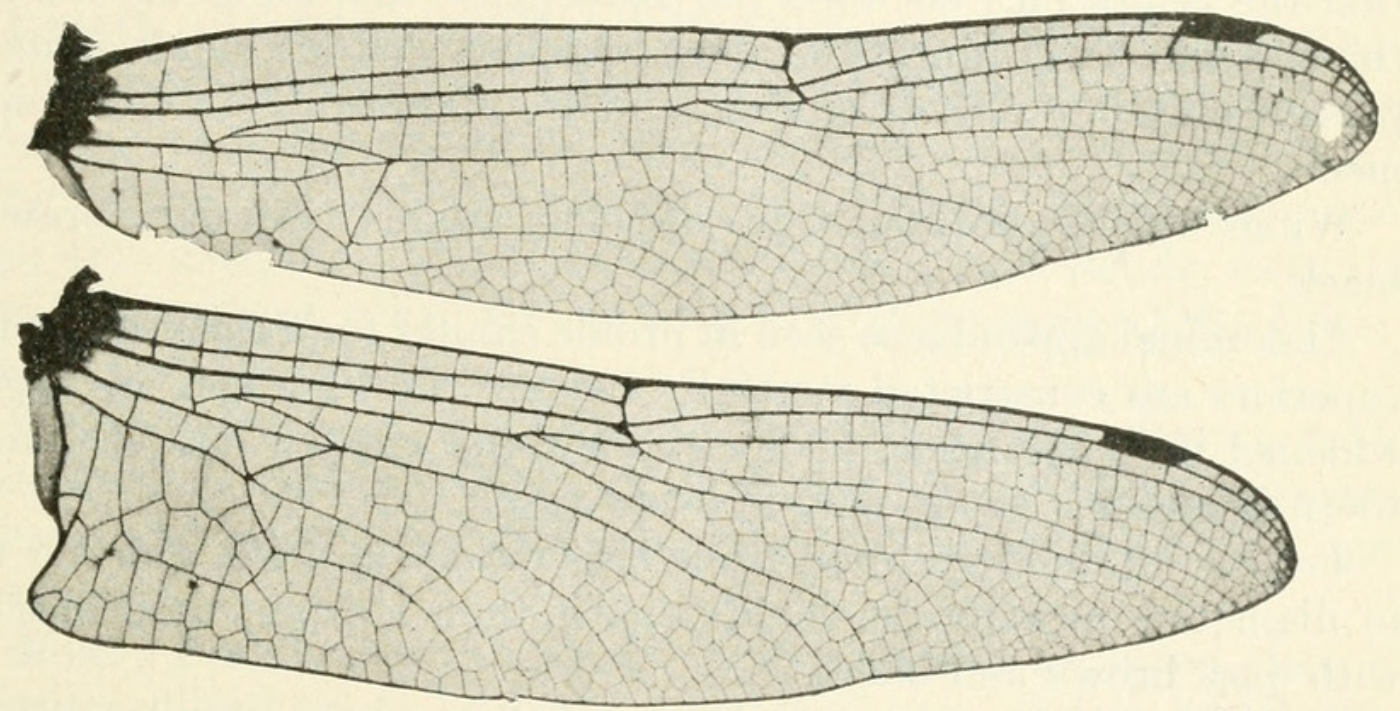

Fig. 4.-Wings of male Macromia wabashensis, Bluffton, Indiana, August 6, 1905.

Unfortunately I have been unable to take a female of this species. Its habits at Bluffton seem indistinguishable from those of tæniolata, with which species and pacifica it is associated. The three species are discussed under pacifica. On living colors of tæniolata and wabashensis I have the following note: Eyes, Hooker's green above; below, in front up to vesicle, and behind up to tubercle, dark nile green; yellow markings, chrome yellow; thorax black, with metallic green reflections; abdomen dead black, velvety in appearance.

Type.-A male, in author's collection, taken at Bluffton, Indiana, June 28, 1908.

Material examined.-All collected by E. B. Williamson, Bluffton, Indiana, June 15, 1902, male; August 6, 1905, male; August 8, 1905, 2 males; August 11, 1907, 2 males; June 28, 1908, male; July 10, 1908, male; August 1, 1908, 2 males (1 P. P. C.); total, 10 males. 
MACROMIA ALLEGHANIENSIS, new species.

Length of abdomen: Male, 51-54 mm.; average, 52.6: female, 56 $\mathrm{mm}$. Length of front wing: Male, $47.5-48 \mathrm{~mm}$.; average, 47.8 ; female, $52 \mathrm{~mm}$. Length of hind wing: Male, $45.5-46 \mathrm{~mm}$.; average, 45.8 ; female, $50 \mathrm{~mm}$. Length of first tibia, male, $8.3 \mathrm{~mm}$.; hind femur, male, $12.1 \mathrm{~mm}$. Length of tibial keel in length of tibia, male: First tibia, $\frac{3}{7}$; middle tibia, $\frac{1}{7}$ to $\frac{1}{5}$.

Without trace of antehumeral thoracic stripe. Latero-ventral metathoracic carina very narrowly yellow posteriorly. Yellow ring on abdominal segment 2 interrupted dorsally, not interrupted at the auricles. Costa dark colored.

Male.-Postclypeus paler than labrum, usually divided by brown into a central and two extremital pale areas; dorsal spots on frons small or wanting.

Abdominal spots similar to illinoiensis, with the striking difference that the yellow on 7 encircles the segment, so that segments $7-9$ have the inferior basal margin of each segment yellow; small spots are present on 5 in 5 of 7 specimens, and are absent on 6 in 6 of 7 specimens.

Wings hyaline, without trace of color; stigma very dark brown or black.

Abdominal appendages seen in profile similar to illinoiensis, but the superiors are constricted ventrally beyond the base and are slightly widened near the apex; in dorsal view the median lateral external tooth is present, but minute in every case.

Female.-Dorsal spots on frons larger than in male, about $1 \mathrm{inm}$. in diameter; postclypeus slightly paler than labrum, both obscured with dark brown and black.

Abdominal spots present on 3-6, smaller posteriorly and scarcely evident on 6 ; large spot on 7 not encircling the segment as it does in the male; inferior lateral basal spots on 7-9 indistinct or wanting, excepting on 8 in 1 female, where they are conspicuous; dorsally $8-10$ are uniform black.

Wings in 1 specimen hyaline; in the other slightly tinged with brown and with veins brown edged, and with a basal trace of brown in the costal space of front wings and in the costal and subcostal spaces of hind wings; stigma black. Two specimens show: Triangle of front wing free, 1 ; crossed, 3 ; subtriangle of front wing free, 1; crossed, 3 ; triangle of hind wing crossed, 4.

Vulvar lamina similar to that of illinoiensis but apparently smaller, shorter, and with the emargination narrower and deeper. Abdominal appendages similar to those of illinoiensis.

This species has been confused with illinoiensis. The length of the first tibia in the female is about 9 , as compared with 7 in illinoiensis. The male may be at once recognized by characters of the 
tibial keel of middle tibia and abdominal markings mentioned above. I have collected all the specimens I have seen but two. Until this study was begun I confused this species with illinoiensis, and I recall nothing striking in its habits in life.

Types.-Male and female in author's collection, taken at Ohiopyle, Pennsylvania, June 24 and June 25, 1900, respectively.

Material examined.-Dunbrooke, Virginia, July 31, 1899, male, R. P. Currie (U.S.N.M.). Ohiopyle, Pennsylvania, June 24, 1900, 2 males, E. B. Williamson. June 25, 1900, 2 males, 1 female, E. B. Williamson (1 male P. P. C.). June 26, 1900, male, E. B. Williamson (U.S.N.M.-Insect Book, pl. 42, fig. 7). September 8, 1901, female, J. L. Graf. Livingston, Kentucky, June 23, 1904, male, E. B. Williamson. A damaged female, collection C. C. Adams, Cleveland, Virginia, August 4, 1899, probably is this species. Total, 7 males, 2 females.

\section{MACROMIA ILLINOIENSIS Walsh.}

Length of abdomen: Male, 47-52 mm.; average, 48.8; female, 47-51 mm.; average, 49. Length of front wing: Male, 42-45.5 mm.; average, 44.1; female, 46-50 mm.; average, 48.2. Length of hind wing: Male, 40-45 mm.; average, 42.4; female, 45-49 mm.; average, 47. Length of first tibia, male, $7 \mathrm{~mm}$.; hind femur, male, 10.7 $\mathrm{mm}$. Length of tibial keel in length of tibia, male: First tibia, $\frac{1}{2}$; middle tibia, $\frac{1}{2}-$ to $\frac{1}{2} \cdot{ }^{a}$

Without trace of antehumeral thoracic stripe. Latero-ventral metathoracic carina brown. Yellow ring on abdominal segment 2 narrow and interrupted at the auricles and dorsum to form 4 spots. Costa dark.

Male.-Postclypeus distinctly paler, clearer in color than the labrum; dorsal spots on frons variable in size, always small, about $0.5 \mathrm{~mm}$. in diameter, and about half as large as the lateral spots; in one specimen dorsal spots are entirely wanting. (There is considerable variation in the coloring of the labrum, especially in the extent of marginal and central black or dark brown, but this seems independent of locality).

Abdominal spots on 3-6 never meeting in the median line, growing smaller posteriorly, present in only 2 cases on 6 , and frequently absent on 4-6; present on 7 as a large dorsal basal spot, posteriorly reaching the transverse carina on either side, produced briefly posteriorly in the mid-dorsal line, not encircling the segment, but limited beneath on the sides by black; segment 8 with a small, narrow, triangular basal spot on either side, the bases of the triangles narrowly separated by the middorsal black line, variable in size and often reduced to mere traces; 8 and 9 (rarely 7 ) ventrally each with a basal yellowish spot on either side. 
Wings hyaline, venation black, in teneral specimens more or less tinged with yellowish; basal costal and subcostal brown spots often present, in their maximum development reaching the first antenodal; wings sometimes fumose beyond the stigma, especially along the anterior margin; stigma yellowish brown to black, apparently depending on age. (See fig. 5.)

Abdominal appendages seen in profile: The upper edge of superiors nearly flat, a slight postero-dorsal elevation at the extreme apex; lower edge beyond the enlarged base nearly parallel to the upper edge, very slightly converging posteriorly, the apex truncate; seen from above the superiors are lyre-shaped, a short basal lateral external carina terminating in a small tooth near the middle of each appendage; this tooth or projection is variable in size, always small, and sometimes not apparent; on the ventral surface distal to this

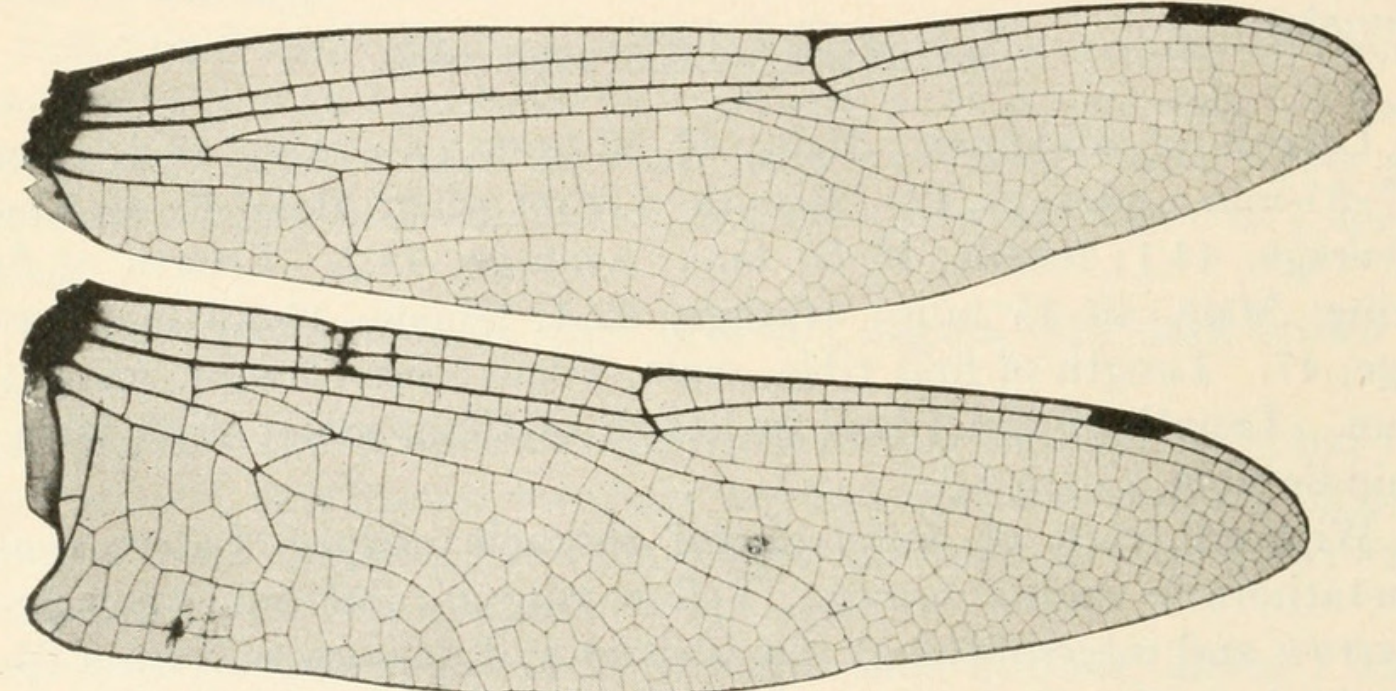

Fig. 5.-Wings of male Macromia illinoiensis, Waterloo, Iowa, June 8, 1906.

tooth the appendage is denticulated; inferior appendage triangular, curved, and equaling or slightly exceeding the superiors.

Female.-Postclypeus more obscured than in the male, especially at either extremity; spots on frons larger.

Abdominal spots larger than in male, excepting on 7 and 8; smallest on 5 and 6 , where they may be lacking entirely; 7 similar to male; dorsal spots absent on 8 , excepting in 2 teneral specimens; inferior lateral basal spots indistinct or absent on 8 and 9 .

Wings hyaline, yellowish brown in several teneral specimens, veins black, brown margined in 2 specimens; basal costal and subcostal brown areas reaching beyond the second antenodal as a maximum; apical fumose area sometimes present, variable in extent, in one case extending basally to nodus; as in the male, the darkest winged specimens are teneral; stigma as in male. The wings of 10 females show the following: Triangle of front wing, free 6 , crossed 14 ; subtriangle of front wing, free 4 , crossed 16 ; triangle of hind wing, free 7 , crossed 13 (compare with same parts in 10 males as tabulated; in rows of 
postrigonal cells, as well as other areas, female Macromias have a larger number of cross-veins than the males). (See fig. 6.)

Vulvar lamina about $\frac{1}{7}-\frac{1}{6}$ length of segment 9, deeply and widely emarginate in a semicircle or right angle. Abdominal appendages equal or very slightly shorter than segment 10 .

I refer to illinoiensis two very similar males, one from Great Falls, Maryland (U.S.N.M.), and the other from Pennsylvania (Acad. Nat. Sci., Phila.). These have abdomen $51 \mathrm{~mm}$. in length and hind wing 46. The Maryland specimen has the tibial keels as usual in illinoiensis, but in the Pennsylvania specimen the keels of the first and middle tibiæ are $\frac{1}{3}+$ and $\frac{1}{3}$ in length of the respective tibiæ. The abdominal spots on 3-6 are conspicuous, those on 6 in the Maryland specimen being about $1 \mathrm{~mm}$. in diameter, and in the Pennsylvania specimen about half as large. It is possible that a larger series would reveal that these 2 specimens are specifically distinct.

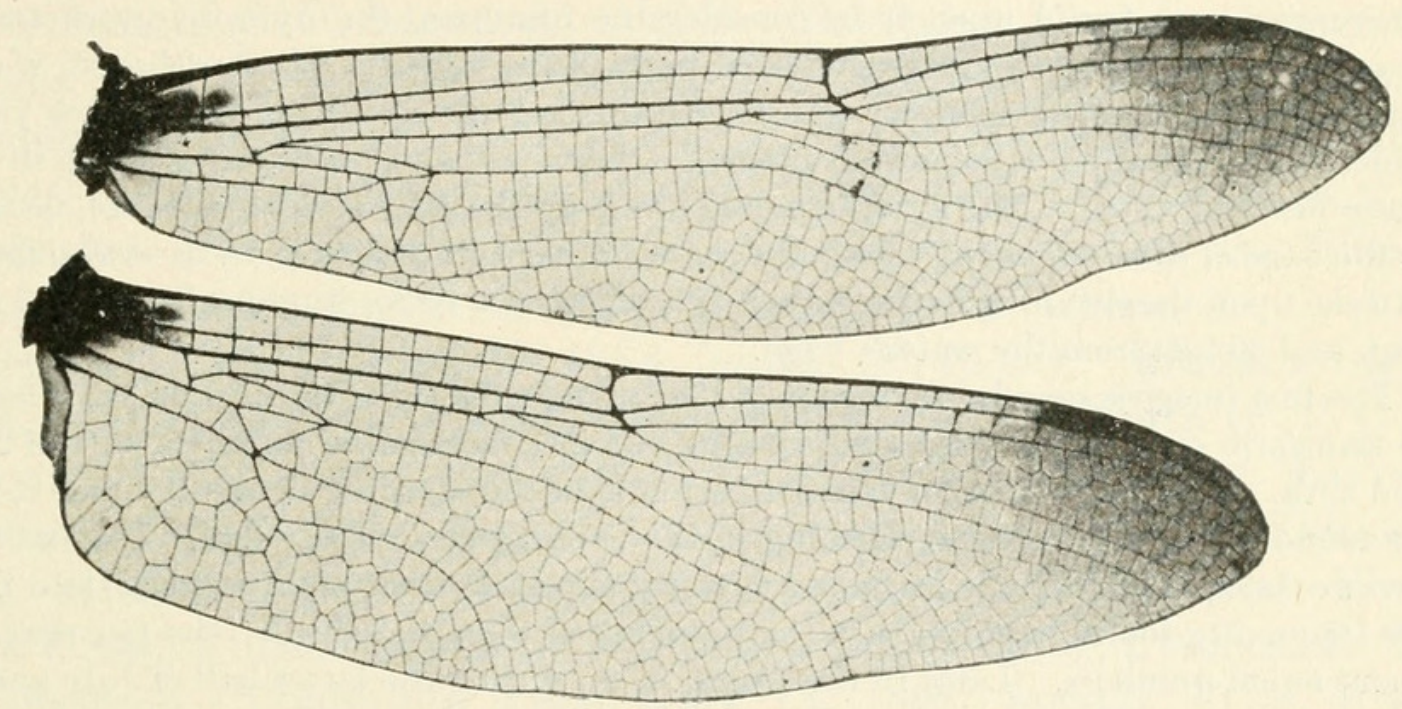

Fig. 6.-Wings of female Macromia illinoiensis, Sandusky, OHio, July 12, 1903.

M. illinoiensis is the best known and most widely distributed of the North American Macromias. Professor Walker, who has observed the species carefully, has written me with reference to its habits, and his remarks are quoted in full:

I have taken the species in but two localities, De Grassi Point, Lake Simcoe, and Go Home Bay, Georgian Bay (both Ontario, Canada), but I have also seen it on the wing on the North River, Algonquin Park, where I have also found the exuviæ. At De Grassi Point the nymphs inhabit the most exposed part of the shore, where the clay banks are about $2-5$ feet high and are strewn thickly along the water's edge with boulders of various sizes, which are pushed up in the spring by the ice. The water is clear and practically free from vegetation, except microscopic forms, and is subject to considerable wave action. The lake is about 2 miles broad at this point, where it forms part of Cookes Bay, the main body of the lake lying farther to the north.

The nymphs climb up the clay banks, crawling sometimes 20 feet or more from the water's edge, and then climb a tree, sometimes to a height of 7 or 8 feet, before transforming. I have never been at De Grassi Point during the season of transformation, and have never seen the imagoes in the oak grove, but always in the glades and along the roads back in the woods, half a mile or so from the spot where the exuviæ are 
found. I have also seen them flying low over the water within 50 yards of the shore, and have once or twice noticed the female flying very close to the water, striking the surface with the tip of the abdomen at intervals of a few yards.

In the glades and wood roads I have taken only the males and have found them most plentiful during July, although they fly till the second or third week of August. The later hours of the afternoon, before sundown, seem to be their favorite time for foraging. They fly very swiftly, in a more or less regular beat up and down a road or opening in a wood, usually about 4 or 5 feet from the ground, but sometimes 15 to 20 feet. They are seldom seen to rest. They disappear before sundown.

At Go Home Bay I have found them in much larger numbers. The shores of this bay are low, well-rounded masses of Laurentian gneiss, exceedingly irregular in contour, and the bay is studded with innumerable rocky islands, more or less sparsely clothed with stunted white pine, red and white oak, aspen, white birch, junipers, Vacciniums of several species, and many other plants, including a great variety of mosses and lichens. The Macromias breed about the rocky shores in all but the most exposed situations. They do not occur in the islands outside the limits of Go Home Bay, i. e., not upon the barren, wind-swept islands of Georgian Bay. The island upon which the biological station is built lies at the mouth of Go Home Bay, and the Macromias were found upon it in considerable numbers, the nymphs transforming most commonly upon the more sheltered parts of the island. The boathouse, which was one of the favorite spots for transformation, is built in a little cove a few yards wide, where the shore is somewhat marshy, a few reeds and pipeworts growing in the water here and there. The nymphs would climb up the sides of the boathouse, usually to the edge of the roof, about 7 feet, but sometimes only 2 or 3 feet. I have also found exuviæ upon the dwelling house, which is built upon a rocky hummock about 12 feet high and 30 feet from the water's edge.

The first imagoes seen in the season of 1907 appeared July 4, but in 1908 they began to transform on June 26, and were coming out in considerable numbers on the 28th and 29th. The usual time for transformation is in the morning between 7 and 8 , but we found one individual transforming in the evening of a cloudy day. For the first two weeks or so in July the imagoes are easily taken, as their flight is weak, and they are frequently found hanging from the branches of trees and shrubs, the two sexes in about equal numbers. Later in the season, i. e., during the latter half of July and in August, they became pretty well distributed through the woods and were seen only occasionally about the island. At this time the females are seldom seen. The woods are for the most part sparse, with numerous open, rocky places, and the Macromias fly back and forth in these openings, frequenting especially openings partly surrounded by a thick growth of trees. There are many depressions in the rocks, which are filled with sphagnum and many bog plants. The openings are surrounded by a zone of black spruce, white birch, and scattered red maples, with an undergrowth of mountain holly, Gaylussacia resinosa, Vaccinium canadense, and a few other plants. The open central parts of these swampy depressions are favorite resorts for Macromia, Epicordulia, and Tetragoneuria.

At Walnut Creek, Putnam County, Indiana, where I took this species along the stream, the flight was very swift, restless, and erratic, though each individual seemed to have a more or less definite range.

Material examined.-Province of Quebec, July 20, 1895, female, Abbe Bégin (P. P. C.). De Grassi Point, Ontario, July 19 and 31, 1901, 2 males, E. M. Walker (E. M. W.); July 25, 1902, male, E. M. Walker (E. M. W.). Go Home Bay, Georgian Bay, Ontario, July 4, 
6, and 13, 1907, 2 males, 1 female, E. M. Walker (E. M. W.); June 26, 28, 29, 30, July 3, 8, 9, and 30, 1908, 9 males, 9 females, E. M. Walker (E. M. W.). Ontario, August 3, 1906, male, E. M. Walker (E. M. W.). Orono, Maine, June 16, 17, 18, and 27, and August 7, 1898, 11 males, 3 females, F. L. Harvey (9 males, 1 female, C. C. A. ; 1 male, 1 female, P. P. C.; 1 male, 1 female, E. B. W.). Intervale, New Hampshire, June, 1899, teneral male (C. C. A.). Sherborn, Massachusetts, male, A. L. Babcock (P. P. C.). Woods Hole, Massachusetts, August, 1875, male, Hagen (M. C. Z.). Oswego, New York, June 26, 1896, teneral male (U.S.N.M.). Fayette County, Pennsylvania, June 18, 1899, male, E. B. Williamson. Rockwood, Pennsylvania, June 29, 1900, female, E. B. Williamson (U.S.N. M.). Pennsylvania, male (Acad. Nat. Sci., Phila.). Great Falls, Maryland, July 4, 1899, male (U.S.N.M.). Abingdon, Virginia, August 13, 1901, female, C. C. Adams (C. C. A.). Cedar Bluff, Virginia, August 1, 1899, female, C. C. Adams (C. C. A.). Cleveland, Virginia, August 1, 2, and 4, 1899, 8 males, 1 female, C. C. Adams (C. C. A.). Oden, Michigan, August 11, 1907, male, L. A. Williamson. Milwaukee River, Milwaukee, Wisconsin, July 25, 1903, male (Mil. Publ. Mus.). Waterloo, Iowa, June 8, 1906, 3 males, 1 female, Newton Miller. Kappa, Illinois, August 5, 1893, 2 males, C. C. Adams (C. C. A.). Belvidere, Illinois, June 29, 1888, female (P. P. C.). Elkhart, Indiana, June 11 and July 4, 1896, male and female, R. J. Weith (P. P. C.); May 28, 1900, teneral female, R. J. Weith (U.S.N.M.). Fort Wayne, Indiana, July 18, 1901, June 17, 1902, 2 males, 1 female, E. B. Williamson. Bluffton, Indiana, June 20, 1901, male, E. B. Williamson. Walnut Creek, Putnam County, Indiana, June 27, 1908, 6 males, E. B. Williamson. Columbus, Ohio, July 13, 1898, female, J. S. Hine (O.S.U.). Sandusky, Ohio, July 12, 1903, 2 males, 1 female, E. B. Williamson; July, 1896, July 20, 1899, 3 males, J. S. Hine. Livingston, Kentucky, June 23, 1904, male, E. B. Williamson. Knoxville, Tennessee, female, Dr. Josiah Curtis (M. C. Z.). Big Creek, Tennessee, female, C. C. Adams (C. C. A.). Sneedsville, Tennessee, Clinch River, August 16, 1899, female, C. C. Adams (C. C. A.). Without data, 4 males, 1 female (2 males, 1 female, O. S. U.; 1 male, M. C. Z.; 1 male, C. C. A.). Total, 68 males, 29 females.

MACROMIA AUSTRALENSIS, new species.

Length of abdomen: Male, 50-52.5 mm.; average, 51.1; female, 50-52 mm.; average, 50.7. Length of front wing: Male, 44.5-48 mm.; average, 45.7 ; female, $48-50 \mathrm{~mm}$; average, 49 . Length of hind wing: Male, 43-47 mm.; average, 44.2; female, 46.5-49 mm.; average, 47.5. Length of first tibia, male, $7.25 \mathrm{~mm}$; hind femur, male, $12 \mathrm{~mm}$. Length of tibial keel in length of tibia, male: First tibia $\frac{3}{7}$ to $\frac{1}{2}-$; middle tibia $\frac{1}{3}-$ to $\frac{3}{8}$. 
A very short antehumeral stripe, $1.5-2 \mathrm{~mm}$. long on the mesepisternum. Latero-ventral metathoracic carina yellow. Yellow ring on abdominal segment 2 not interrupted dorsally or laterally. Costa dark colored.

Male.-Postclypeus and labrum similar to illinoiensis; dorsal spots on frons rounded, in size from scarcely perceptible to nearly $1 \mathrm{~mm}$. in diameter, and always larger than the lateral spots.

Abdominal spots on 3-6 larger than in illinoiensis, growing successively smaller posteriorly, the spot on 3 extended ventrally on either side to meet a longitudinal stripe on the ventral edge of the segment (in illinoiensis the dorsal spot is widely separated from the ventral longitudinal stripe); on 3-5 the spots on each segment are separated dorsally by the faintest line of black or the black line may be wanting; in two cases the spots on 6 meet dorsally; the greatest variation in size of spots is on 6 , where the spots may be widely separated and about $0.5 \mathrm{~mm}$. long, or joined dorsally and $1.5 \mathrm{~mm}$. in length; spots never wanting on $3-6 ; 7$ similar to illinoiensis; spot on $8 \frac{1}{2}$ to $\frac{3}{4}$ as long as on 7 , divided dorsally in only one case, and then by the merest line of black.

One male from Wister, Oklahoma, is very dark and may not belong here; the tibial keels are like australensis, but the coloration is more like illinoiensis. However, the head is like a very dark illinoiensis, while the abdomen has an unusual amount of yellow for illinoiensis; the antehumeral stripe seems to be wanting and the yellow ring on 2 is narrowly interrupted dorsally and laterally; well developed spots are present on 6 and 8 . In australensis 7 may be yellow or not on the ventral basal edge of the segment; in any case the yellow is less distinct than on 8 and 9 .

Wings hyaline, without trace of color anywhere even in teneral specimens; stigma black.

Abdominal appendages indistinguishable from illinoiensis.

Female.-Head similar to illinoiensis, but dorsal spots on frons apparently not larger than in male. Abdomen similar to male, but spots on 3-6 more nearly uniform in size, slightly smaller on $6,1.5-2$ $\mathrm{mm}$. long on 3-5; dorsal spot present on 7 ; inferior lateral basal spots present on 7-9.

Wings hyaline, short brown basal streaks in the costal or costal and subcostal areas; apex of wings slightly fumose in two specimens; stigma yellowish brown to black. The wings of three females show the following: Triangle of front wing, free 1, crossed 5; subtriangle of front wing, free 1 , crossed 5 ; triangle of hind wing, crossed 6 .

I can not be sure of the shape of the vulvar lamina; it seems to be a very short, scarcely emarginate plate; appendages similar to illinoiensis.

Types.-Male and female, author's collection taken at Wister, Oklahoma, Poteau River, Frank Collins, August 3, 1907. 
Material examined.-Wister, Oklahoma, Poteau River, August 3, 5, and 6, 7 males, 2 females, Frank Collins. Dallas, Texas, male and female, Ball (M. C. Z.). Total, 8 males, 3 females.

Under this name I have included 3 males, which future material and study may reveal are specifically distinct.

Length of abdomen, 50.5-54 mm. Length of front wing, 46.5-48 $\mathrm{mm}$. Length of hind wing, 44-47 mm. Length of first tibia, 7-7.5 $\mathrm{mm}$; hind femur, 11-12 mm. Length of tibial keel in length of tibia: First tibia, $\frac{1}{2}-$ to $\frac{1}{2}$; middle tibia, $\frac{2}{5}$.

The yellow ring on 8 is narrowed laterally, widened dorsally and ventrally, and encircles the segment; in all the other material of australensis the dorsal and ventral yellow areas on 8 are separated by black, excepting in one individual where the abdominal spots are very large with the yellow spot on 6 not divided in the median dorsal line by black; in the 3 males under discussion the spots on 6 vary from $0.5-1 \mathrm{~mm}$. in diameter and are distinctly to widely separated in the middorsal line. The stigma is yellow-brown to black.

Material examined.-Hyattsville, Maryland, July 4, 1899, male, J. S. Hine. Gynn's Button Mill, Maryland, September 20, male (M. C. Z.). Blount Springs, Alabama, July 18, 1890, male, Charles C. Deam. Total, 3 males.

MACROMIA GEORGINA de Selys.

Length of abdomen: Male, 50.5-54 mm.; average, 51.8; female, 54 $\mathrm{mm}$. Length of front wing: Male, $47.5-50 \mathrm{~mm}$; average, 48.8; female, $53 \mathrm{~mm}$. Length of hind wing: Male, $46-48 \mathrm{~mm}$; average, 47; female, $51 \mathrm{~mm}$. Length of first tibia, male, $8 \mathrm{~mm}$; hind femur, male, $12 \mathrm{~mm}$. Length of keel in length of tibia, male: First tibia, $\frac{2}{5}$; middle tibia, $\frac{1}{4}$ to $\frac{2}{7}$.

Humeral stripe present, about $3 \mathrm{~mm}$. long on the mesepisternum; otherwise similar to australensis.

Male.-Very close to australensis; the abdominal spots on 3-6 decreasing in size very slightly posteriorly; spots on 7 and 8 encircling the segments. Abdominal appendages similar to australensis and illinoiensis, but the superiors have a small, distinct, basal, dorsal yellow area, and the inferior appendage is distinctly paler than the superior appendages.

Female.-Separated from australensis by the longer antehumeral thoracic stripe and the larger abdominal spots, especially on $3-5$ (1-2 mm. long in australensis; $1.5-2.5$ in georgina). The vulvar lamina is a very short plate with converging sides, broadly and shallowly emarginate.

This is the only species in the material before me to which, I believe, Epophthalmia georgina de Selys can be referred. In the female the stigma is yellow-brown, the costa obscure yellowish brown (in the male the costa has the basal median area yellow, but this yellow disappears with the narrowing of the costa which beyond this point 
is dull brown). There is nothing in de Selys's description and Martin's recent figure which conflicts with the specimen before me unless it be the form of the vulvar lamina. The triangles of all four wings and the subtriangles of the front wings are all crossed.

To this species I refer a badly faded female in the Museum of Comparative Zoology labeled "Texas," though in this specimen all triangles and subtriangles are free.

Material examined.-Raleigh, North Carolina, July 31 and August 30, 1902, August 9, 1904, June 30, 1905, and September 12, 1907, 4 males, 1 female, C. S. Brimley (C. S. B.) ; 1 male with last 5 abdominal segments gone. Texas, female (M. C. Z.). Total, 4 males, 2 females.

\section{MACROMIA PACIFICA Hagen.}

Length of abdomen: Male, 48.5-53 mm.; average, 50.9; female, 46.5-53.5 mm.; average, 50.6. Length of front wing: Male, 43.5-50 $\mathrm{mm}$; average, 47.2 ; female, $46-53 \mathrm{~mm}$; average, 49.3 . Length of hind wing: Male, 41.5-48 mm.; average, 45.3; female, 44.5-49.5 mm.; average, 47.3. Length of first tibia, male, $7.5 \mathrm{~mm}$; hind femur, male, $11.8 \mathrm{~mm}$. Length of tibial keel in length of tibia, male: First tibia, $\frac{3}{7}$ to $\frac{1}{2}-$; middle tibia, $\frac{1}{3}$ to $\frac{3}{7}$.

Antehumeral thoracic stripe well developed, separated at its upper end from the antealar sinus by about its own width. Latero-ventral metathoracic carina brown or rarely very narrowly yellow. Yellow ring on abdominal segment 2 very wide, narrowly interrupted dorsally by a posteriorly projected middorsal black line which in a few males does not completely traverse the yellow. Costa distinctly yellow to the wing tip.

Male.-Postclypeus green-yellow, labrum dull yellow; dorsal spots on frons occupying the entire surface but the median sulcus, continuous just in front of the antennæ with the lateral spots (rarely separated by brown, the separation narrowest posteriorly); lateral spots are about equal in size or smaller than the dorsal spots.

Abdominal spots large, but on 3-6 divided dorsally by a narrow black line; the spots occupy the area anterior to the transverse carina on each segment but 7 and 8 , where they are continued posteriorly, and in length of each segment are about as follows: On $3, \frac{1}{2}$ to $\frac{1}{2}+$; on $4, \frac{1}{2}$ - to $\frac{1}{2}$; on $5, \frac{1}{3}+$; on $6, \frac{1}{3}$; on $7, \frac{1}{2}$ to $\frac{2}{3}$; on $8, \frac{2}{5}$ to $\frac{1}{2}$; the dorsal separation is widest on 3 and the spots on this segment are separated from the base of the segment by black about $1 \mathrm{~mm}$. wide; on 4-6 the spots are quadrangular and are separated from the base of each segment by about $0.5 \mathrm{~mm}$.; on 7 and 8 the spots reach the base of each segment; spots on 7 and 8 have a triangular posterior projection on either side of the middorsal line; spots on 3 and 7 are separated from the inferior spots on each segment or are narrowly connected just anterior to the transverse carina; spot on 8 encircles the 
segment; 9 usually shows the vestige of a basal spot on either side of the middorsal line; beneath 8 is always spotted basally on either side, 9 usually, and 7 obscurely, if at all.

Wings hyaline to strongly tinged with yellowish, usually slightly tinged; rarely a minute basal brown spot in the costal space; stigma black. (See fig. 7.)

Appendages similar to illinoiensis but slightly straighter and longer (2.5 mm. in illinoiensis; $3 \mathrm{~mm}$. in pacifica); median external tooth small but always present; superiors and inferior about equal in length; the superiors with an external basal yellow spot, variable in size.

Female.-Similar to male; yellow ring on 2 always interrupted dorsally; other spots as in the male bounded posteriorly by the transverse carina, excepting on 7 and 8 , and sometimes 6 , when they are produced slightly posteriorly; the ventral spots on the posterior seg-

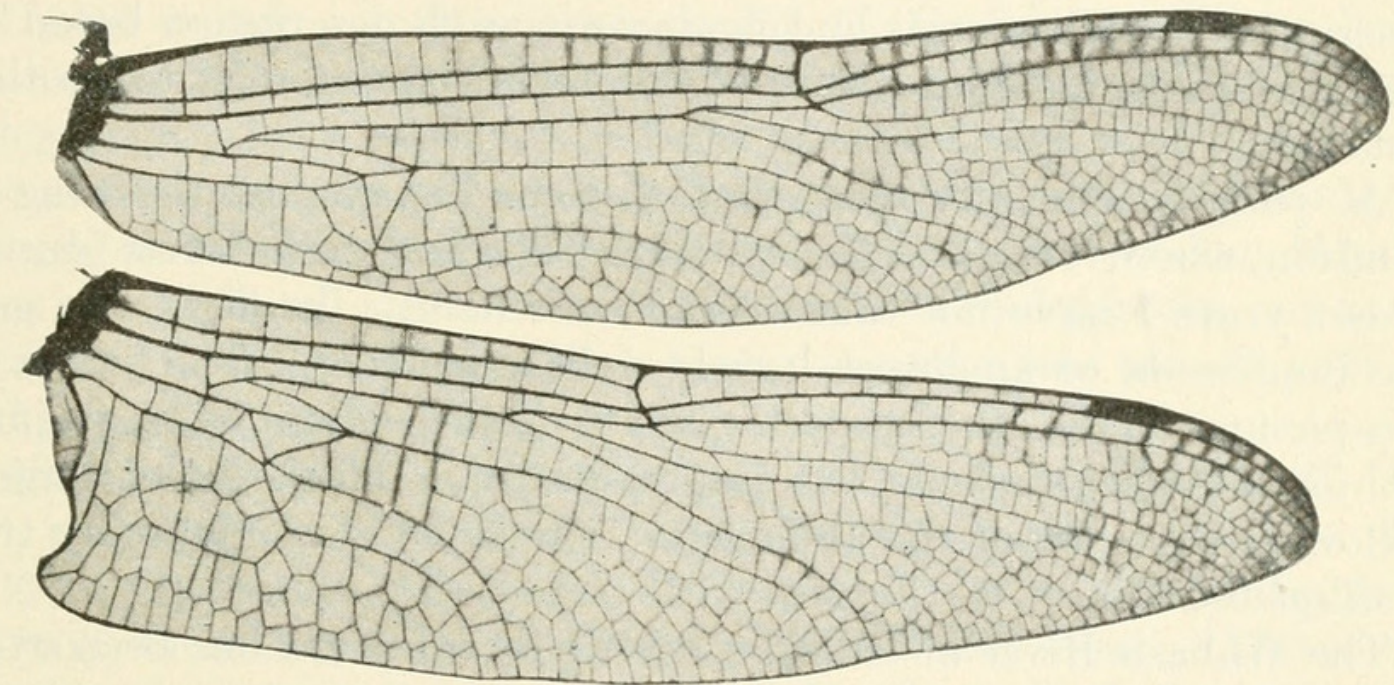

Fig. 7.-Wings of male Macromia pacifica, Bluffton, Indiana, August 19, 1906.

ments are plainly present only on 8 and sometimes not there; dorsal and inferior lateral spots on 3,7 , and 8 separated.

Wings hyaline to deeply yellowish tinged, the color most pronounced distal to the triangles; basal costal spots small, not reaching the first antenodal in any case. The wings of 7 females show the following: Triangle of front wing, free 7 , crossed 7 ; subtriangle of front wing, free 1, crossed 13; triangle of hind wing, free 7 , crossed 7 . Vulvar lamina not exceeding the eighth segment, developed only as a short, troughlike fold at the apex of the sternum. Abdominal appendages similar to illinoiensis.

I have been able to positively identify this species through the kindness of Mr. Henshaw, who loaned me Hagen's type as well as the types of annulata. The type of pacifica is a collection of fragments (about 20 in number) as stated by Hagen. These are carefully arranged and glued on a piece of cardboard and are sufficient to identify the species.

Proc.N.M.vol.37-09-25 
In pacifica, annulata, and magnifica the dorsal spots on 4-6 occupy all or nearly all the area between the base of each segment and the transverse carina. The only species with which annulata and pacifica might be confused in length of antehumeral thoracic stripe is georgina, which has the abdomen with relatively much more black, the yellow on 4-6 widely separated from the base of each segment. Both magnifica and georgina have the antehumeral thoracic stripes shorter than in annulata and pacifica. Magnifica is, moreover, distinct by a number of characters (see description of magnifica), leaving annulata as the only species which might be confused with pacifica. In annulata and magnifica the dorsal stripes on 4-6 are not interrupted with black in the middorsal line, and the latero-ventral metathoracic carina is broadly yellow. For other characters, see descriptions of annulata and magnifica. There is no doubt that flavipennis Walsh is a synonym of pacifica and not of annulata as Hagen supposed. In Walsh's descriptions of illinoiensis and flavipennis, each description based on a single female, his descriptions of the vulvar lamina refer to another structure.

$M$. pacifica is readily recognized at some distance on the wing at Bluffton, where it is associated with tæniolata and wabashensis (during recent years I have not taken illinoiensis here). In flight one gets the impression of an insect largely yellow in color. The yellow is conspicuous on the other 2 species, but to no such extent as on pacifica. M. illinoiensis gives one the impression of a black insect largely yellow at the apex of the abdomen. The same is undoubtedly true of alleghaniensis.

The Wabash River at Bluffton during recent years has been overrun at the ripples by willow herb, so the river in summer is reduced to a succession of pools of greater or less length. On the banks Hibiscus militaris has become thoroughly established at the water's edge. These pools seem to be an ideal home for the Macromias. (See pls. 35 and 36.)

The flight of pacifica is generally less swift than that of tæniolata and wabashensis and it ranges less widely, patrolling possibly only one pool, while the others return to the same point only after longer intervals. Individuals of all 3 species follow the same track over and over, crossing the river at a certain point, returning over a certain patch of willow herb, turning out from the shore line at a certain clump of hibiscus, and going and coming over the same or nearly the same course and not following the pools in a circular manner. Moreover, individuals of successive generations have followed the same course as their predecessors, as I have observed at the pools where I have found individuals most numerous and where I have collected for several years. The configuration of vegetation and water is a positive factor in determining the course of flight. Much of my suc- 
cess in collecting these dragonflies is due to a recognition of this fact, for the knowledge that one is waiting for the appearance of a dragonfly at the particular point near which that insect will return, even though a great breadth of water and willow herb lies all about, instills in one that patience which is essential in collecting these insects. The use of the word success in the above sentence may be questioned; many fruitless days have been spent wading the Wabash.

Males capture the females over the water, sometimes chasing them to great heights. The pairs come to rest in trees or bushes. The females oviposit unattended by the males, following the shore line very closely, ranging back and forth over a short distance, and hovering and striking the abdomen into the water. Fights between males are not rare, though I am not sure that males of the same species fight. In the few cases I have been able to determine certainly 2 species have been involved.

Under certain conditions specimens of Cordulegaster have been reported as being very easily taken with an insect net. The few Cordulegasters I have captured in flight have not been such easy prey, and at the present time I can not distinguish Macromias and Cordulegasters on the wing. At the same time I have never taken Macromias at such small streams as I have found Cordulegasters, nor have I taken Cordulegasters at such larger streams (see pls. 35, 36) as Macromias frequent.

Material examined.-Hagen's type, Pacific Railroad survey, lat. $38^{\circ}$, male (M. C. Z.). Waco, Texas, May 25, male and female (M. C. Z.). Milwaukee, Wisconsin, Milwaukee River, cement mills, July 2, 1902, teneral female, V. Fernekes (Mil. Publ. Mus.). Mahomet, Illinois, June 10, 1898, teneral female, C. C. Adams (C. C. A.). Kappa, Illinois, July 13, 1895, male, C. C. Adams (C. C. A.). Bluffton, Indiana, June 15 and August 3, 1902, male, 2 females; August 8 and 13, 1905, 2 males; August 19, 1906, male; August 11, 1907, 4 males; June 28, July 10, and August 1, 1908, 14 males, 2 females. Total, 25 males, 7 females.

\section{MACROMIA ANNULATA Hagen.}

Length of abdomen: Male, 52-54 mm.; average, 52.6; female, 52-55 mm. Length of front wing: Male, 45-48.5 mm.; average, 46.5 ; female, 50-52 mm.; average, 51.3. Length of hind wing: Male, 44-46 mm.; average, 45; female, 48-50 mm.; average, 49. Length of first tibia, male, 7.5 ; hind femur, male, 12 . Length of tibial keel in length of tibia, male: First tibia, $\frac{1}{2}$; middle tibia, $\frac{2}{5}$.

Antehumeral thoracic stripe long, separated above from the antealar sinus by about its own width or slightly more. Latero-ventral metathoracic carina broadly yellow. Yellow ring on abdominal segment 2 very wide, uninterrupted (in one specimen there is a faint, middorsal, longitudinal pale-brown streak) ; apex of segment 1 laterally 
with a yellow streak (the only North American Macromia in which segment 1 is not laterally concolorous). Costa distinctly yellow to the wing tip. Femora pale basally.

Of this species I have seen only Hagen's 6 types, 3 of each sex, kindly loaned me by Mr. Henshaw. It is possible that the color of these specimens may be very different from the colors in life. However, no other basis for description than these specimens is before me.

Male.-General color pale reddish brown, darkest on abdominal segments 3-6. Face very light yellow, nearly white, frons in front and anteclypeus slightly darker; lips and rear of eyes, excepting the dorsal third, the same pale color; a very narrow brown streak in sulcus of frons; the lateral pale areas extensive and extending to postclypeus; vesicle pale (a character it shares only with magnifica).

Abdominal spots large, not separated dorsally on 3-8, otherwise similar to pacifica, but less distinct (i.e., less sharply defined) and the merest trifle more separated by dark color from the base of each segment; beneath $7-10$ are largely pale colored, especially basally; dorsal spot on 3 broadly connected posteriorly with the inferior pale longitudinal area, leaving only a basal ring and a posterior projection from this on either side dark colored; spots on 7 and 8 encircling the segments basally.

Wings hyaline; stigma yellowish brown.

Abdominal appendages distinctly different from those of other species; seen from above the superiors are straighter and much wider beyond the median external tooth than in any other species; in pacifica, for example, they taper continually from the tooth to the apex, while in annulata they widen from the tooth to before the apex, which is broadly rounded; seen in profile the same is true, and instead of the upper and lower edges converging slightly there is a distinct subapical inferior dilatation; there is an indistinct, pale, dorsal basal area; the inferior appendage is slightly but distinctly shorter than the superiors.

Female. - Similar to the male, but the dorsal spots on 4 are distinctly and on 5 and 6 indistinctly connected just anterior to the transverse carina with extensive but indefinite and suffused inferior lateral longitudinal stripes; there are faint traces of dorsal basal spots on 9 and 10.

Wings hyaline, the faintest trace of basal brown in the costal spaces. Three females show all triangles and subtriangles free.

Vulvar lamina apparently much as in pacifica, not distinct, but there seems to be a slight projection posteriorly on either side of the trough. Abdominal appendages similar to illinoiensis.

Material examined.-Pecos River, June 26, July 13, August 4, and 1 female without date, 3 males, 3 females, Captain Pope (M. C. Z., all bearing Hagen's red and white card type labels). Total, 3 males, 3 females. 
MACROMIA MAGNIFICA McLachlan.

Length of abdomen: Male, 46.5-49 mm.; female, 50-51.5 mm. Length of front wing: Male, 45-46 mm.; female, $48 \mathrm{~mm}$. Length of hind wing: Male, $44 \mathrm{~mm}$.; female, $46 \mathrm{~mm}$. Length of first tibia, male, 7.5; hind femur, male, 12-12.5. Length of tibial keel in length of tibia, male: First tibia, $\frac{1}{2}$; middle tibia, keel wanting.

Antehumeral thoracic stripe long and wide, shorter than in annulata and pacifica, and separated above by about $2 \mathrm{~mm}$. from the antealar sinus. Latero-ventral metathoracic carina broadly yellow. Yellow ring on abdominal segment 2 wide, interrupted in the middorsal line (in one specimen narrowly continuous over middorsal line at the extreme apex of the ring), interrupted laterally at level of auricles and with little or no pale color ventral to the level of the auricles. Costa distinctly yellow to stigma or wing tip.

Male.-Frons in front, sulcus above, anteclypeus, and base of labrum reddish brown; rear of eyes shining black, as usual in the genus; remainder of head pale, nearly white, including the vesicle; lateral spots on frons about the same size as dorsal spots with which they are continuous.

Thorax rich reddish brown, apparently pruinose; dark area of abdomen darker colored. Dorsal abdominal spots large, excepting basal spots on 9-10, which are small and indistinct; on 3-8 separated from base of segment by little more than a line of black; on 7 and 8 extended posteriorly beyond the transverse carina; not interrupted dorsally on 3-8; dorsal spot connected with inferior lateral stripe only on segment 8 and very narrowly there (segment 3 in magnifica is thus very differently patterned from the same segment in annulata); distinct ventral basal spots on 8 and 9 .

Wings hyaline; stigma very dark brown or black.

Abdominal appendages distinctly different from those of all other American species; the superior appendages seen from above straighter, without trace of median external tooth, the apices less divergent; seen in profile they are heavier just beyond the base than in illinoiensis and the upper and lower edges converge continuously to the apex; there is a distinct, pale, basal external area on each superior; the inferior is broad, triangular, and slightly shorter than the superiors.

Female.-Similar to the male; dorsal pale spot on 3 produced posteriorly more or less beyond the transverse carina (the merest hint of this shows in the male; moreover, there is on 4-6 in both sexes a very slight, scarcely distinct, posterior projection of the dorsal spots beyond the transverse carina); dorsal spot on segment 3 narrowly interrupted in the middorsal line; all dorsal spots isolated from inferior lateral pale areas.

Wings hyaline or slightly tinged with faint yellowish at base and anteriorly beyond the nodus; stigma colorless, yellowish brown or 
black, depending on age. Three females show all triangles and subtriangles free; and 8 antenodals in 4 hind wings, and 9 in 2.

Vulvar lamina forklike, about one-seventh length of 9; abdominal appendages as in illinoiensis.

In its venational and accessory sexual characters, and the absence of a tibial keel on the middle tibia in the male, this species stands the most sharply defined of all North American Macromias.

Material examined.-Fresno, California, June 11 and July 21, 1900, 2 females, E. A. Schwarz (U.S.N.M.). Tucson, Arizona, 2 males (M. C. Z.). Arizona, Cornell Univ. Lot 35, Morrison, female (M. C. Z.). Total, 2 males, 3 females.

\section{VENATIONAL CHARACTERS OF NORTH AMERICAN SPECIES OF} MACROMIA (MALES).

The tabulation below is based on the following material:

M. tæniolata, 10 specimens; 1 Toledo, Ohio; 5 Fort Wayne, Indiana;

4 Bluffton, Indiana.

M. wabashensis, 10 specimens; all Bluffton, Indiana.

M. alleghaniensis, 5 specimens; 3 Ohiopyle, Pennsylvania; 1 Dunbrooke, Virginia; 1 Livingston, Kentucky.

M. illinoiensis, 10 specimens; 2 De Grassi Point, Ontario; 1 Orono, Maine; 1 Fayette County, Pennsylvania; 1 Sandusky, Ohio; 1 Fort Wayne, Indiana; 1 Putnam County, Indiana; 1 Livingston, Kentucky, 1 Milwaukee, Wisconsin; 1 Waterloo, Iowa.

M. australensis, 7 specimens; 6 Wister, Oklahoma; 1 Dallas, Texas.

M. australensis?, 3 specimens; 2 Maryland; 1 Alabama.

M. georgina, 4 specimens; Raleigh, North Carolina.

M. pacifica, 10 specimens; 8 Bluffton, Indiana; 1 Waco, Texas; 1 Kappa, Illinois.

M. annulata, 3 specimens; Pecos River.

M. magnifica, 2 specimens; Tueson, Arizona. 


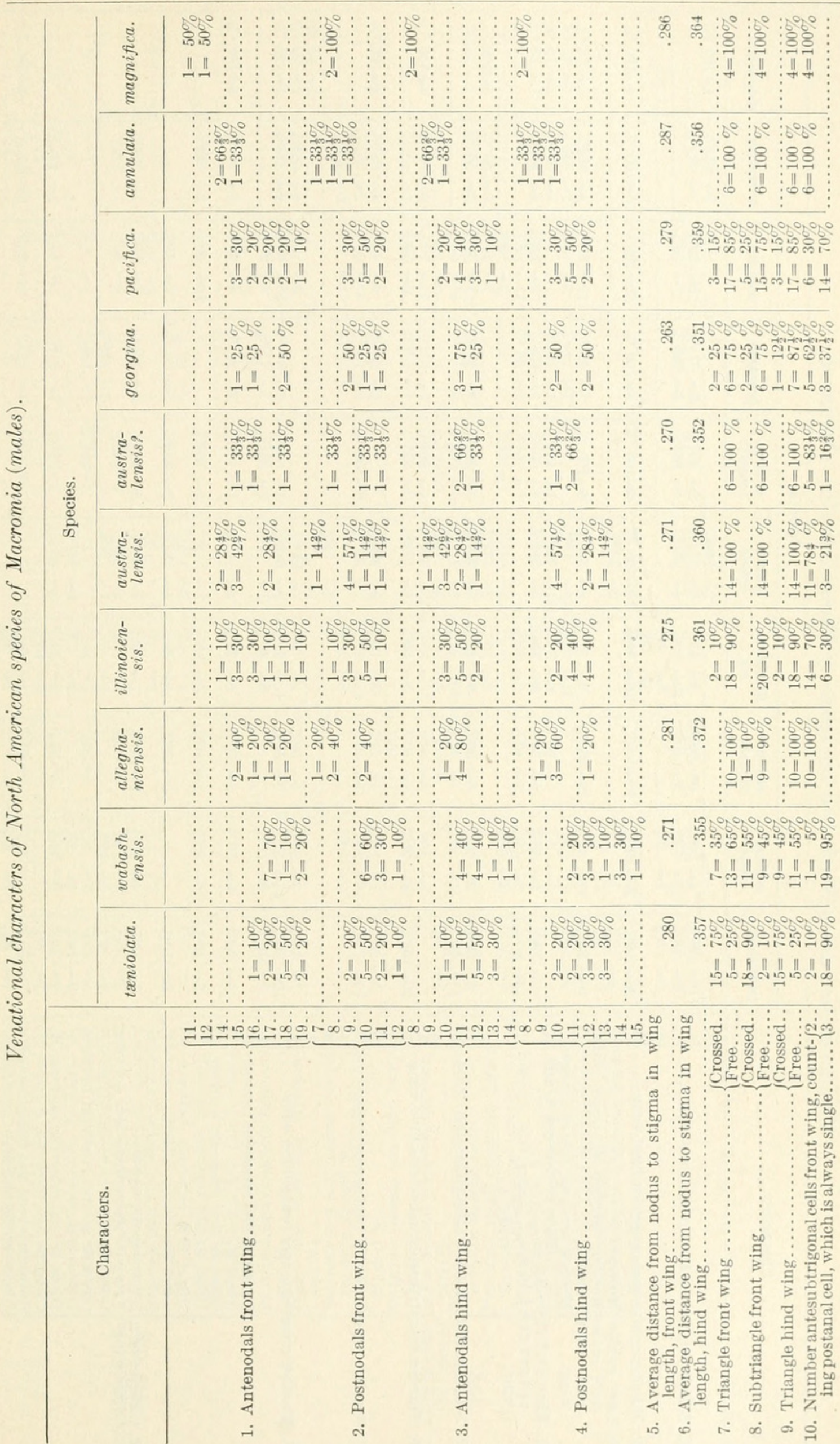




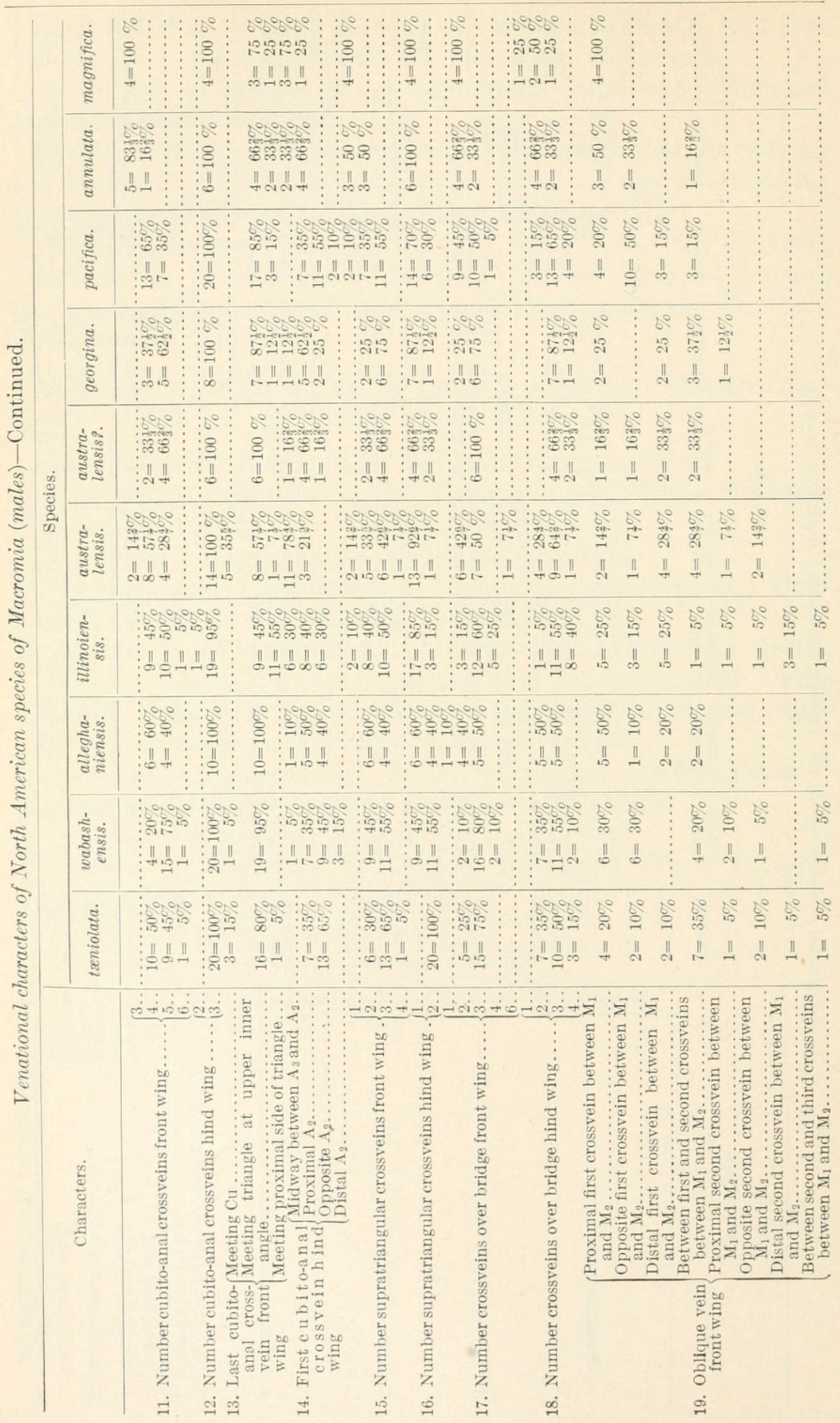




\section{$\stackrel{20}{8}$}

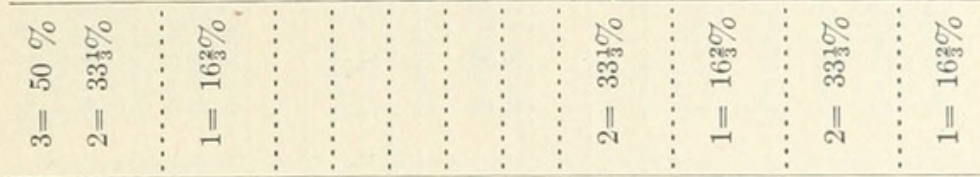

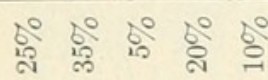

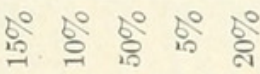

II

لI

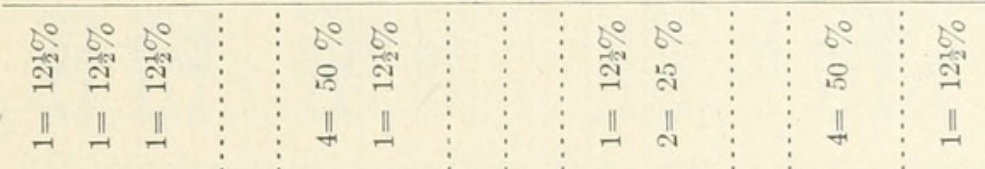

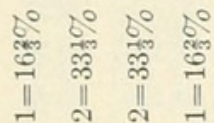

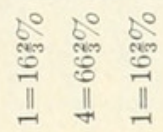

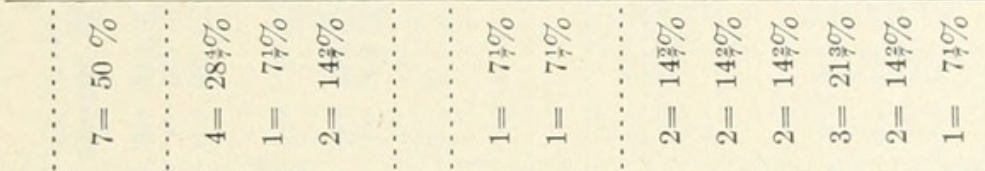

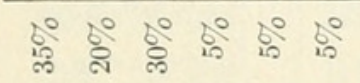

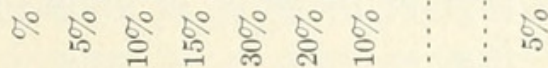
II II

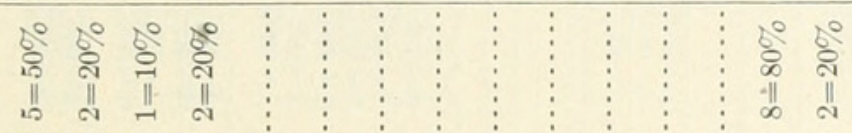

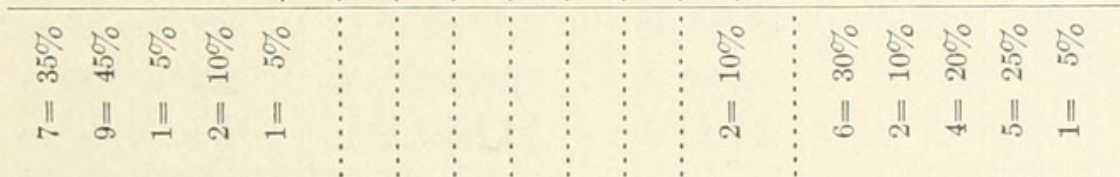

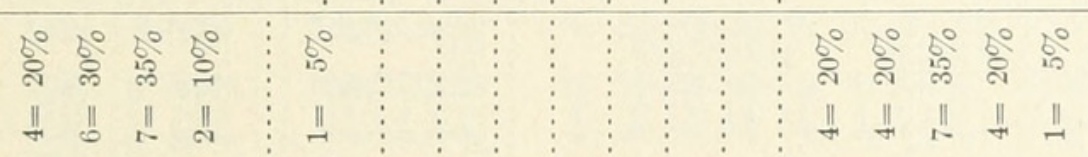

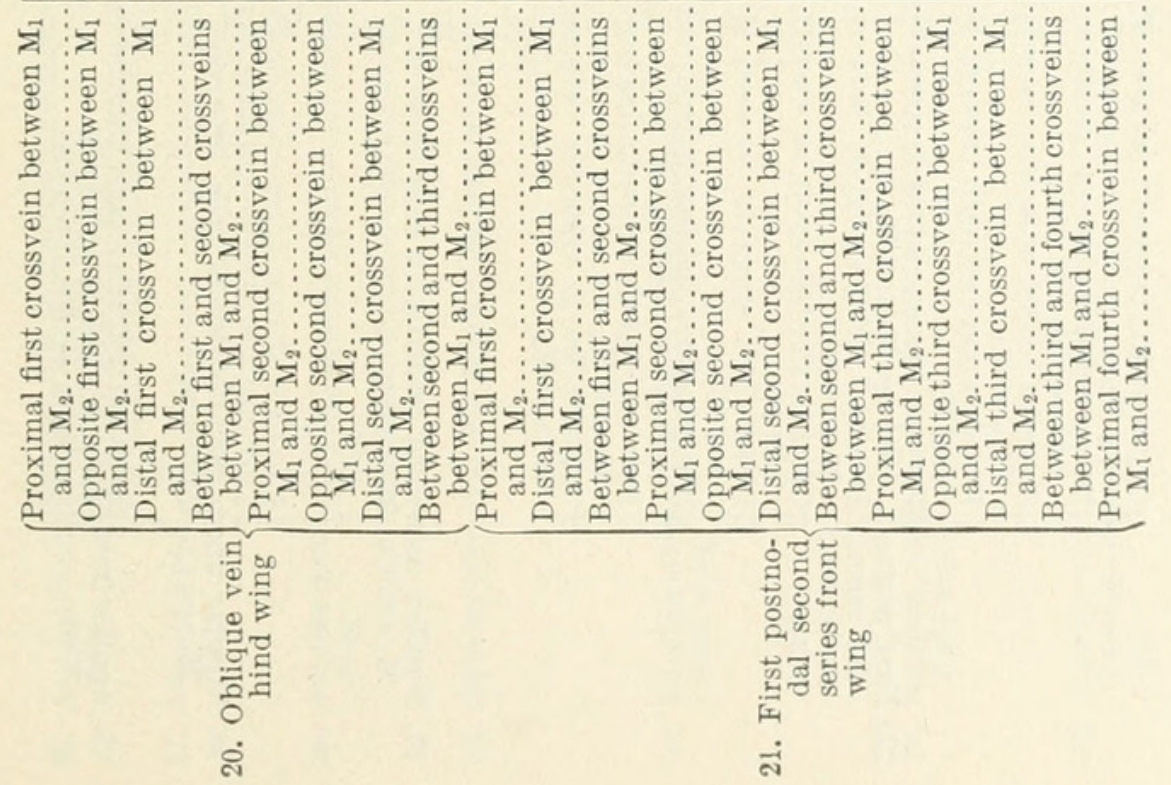




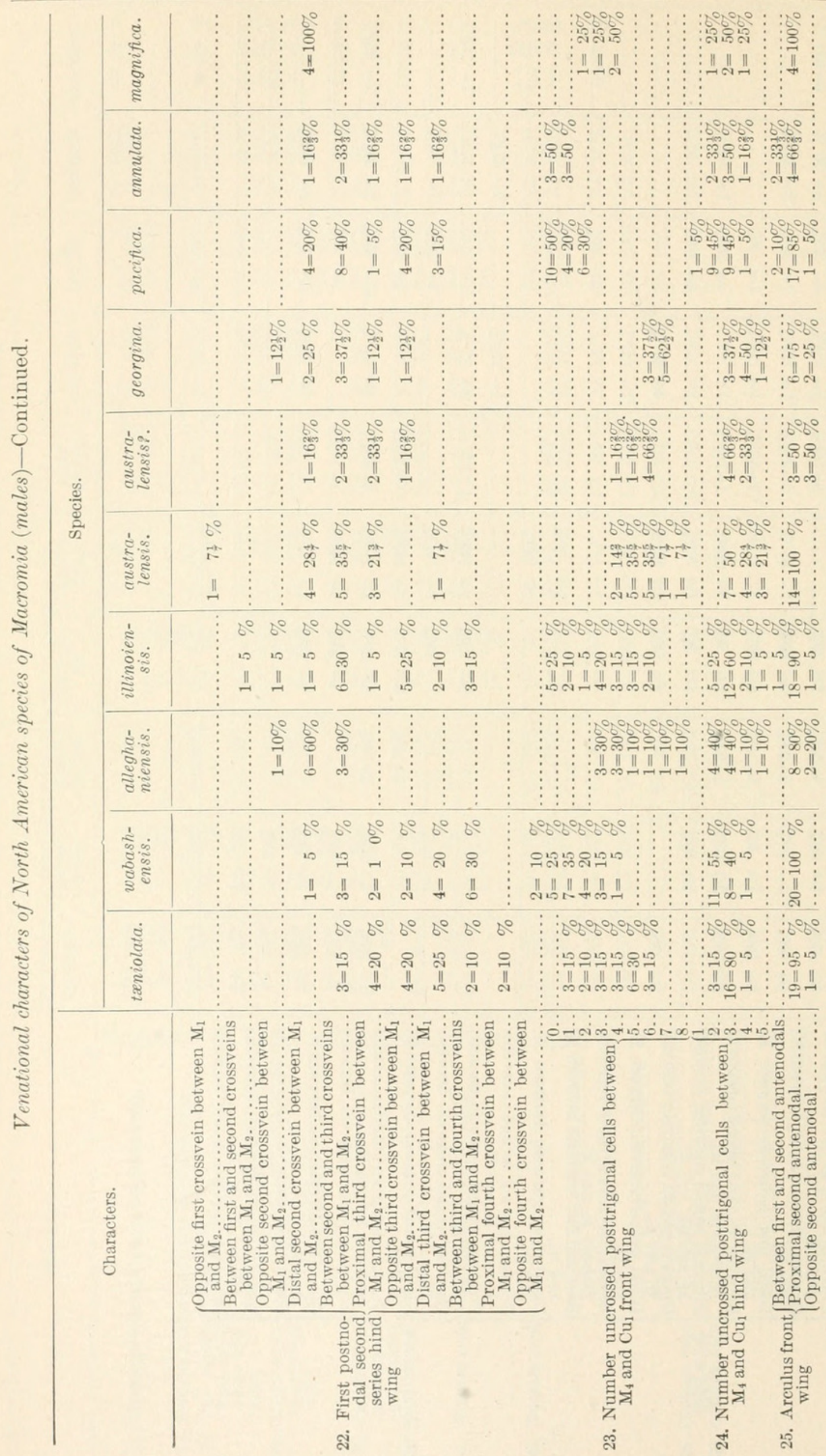


No. 1710. NORTH AMERICAN DRAGONFLIES--WILLIAMSON.

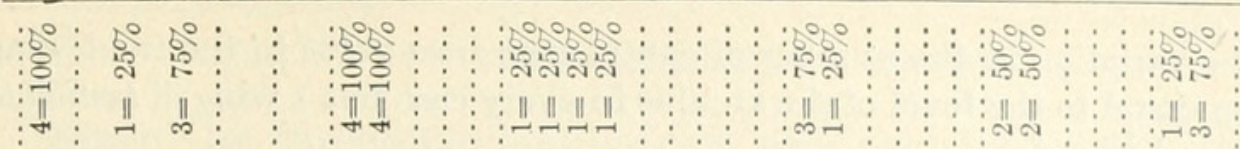

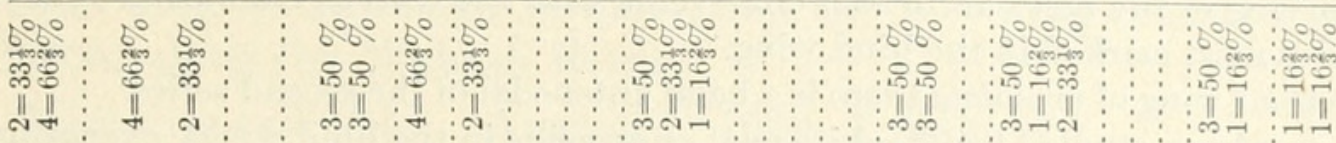

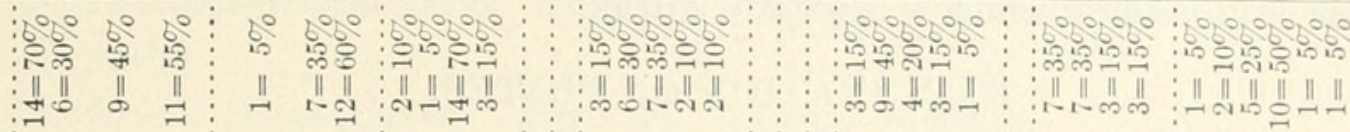

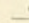

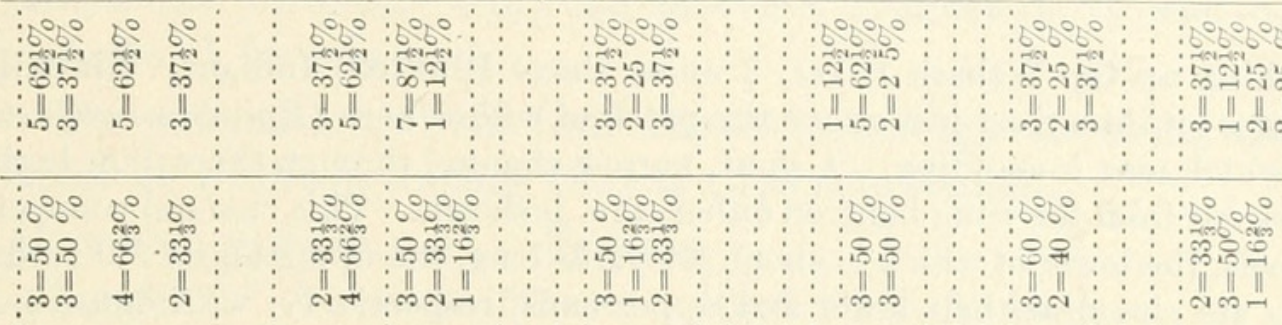

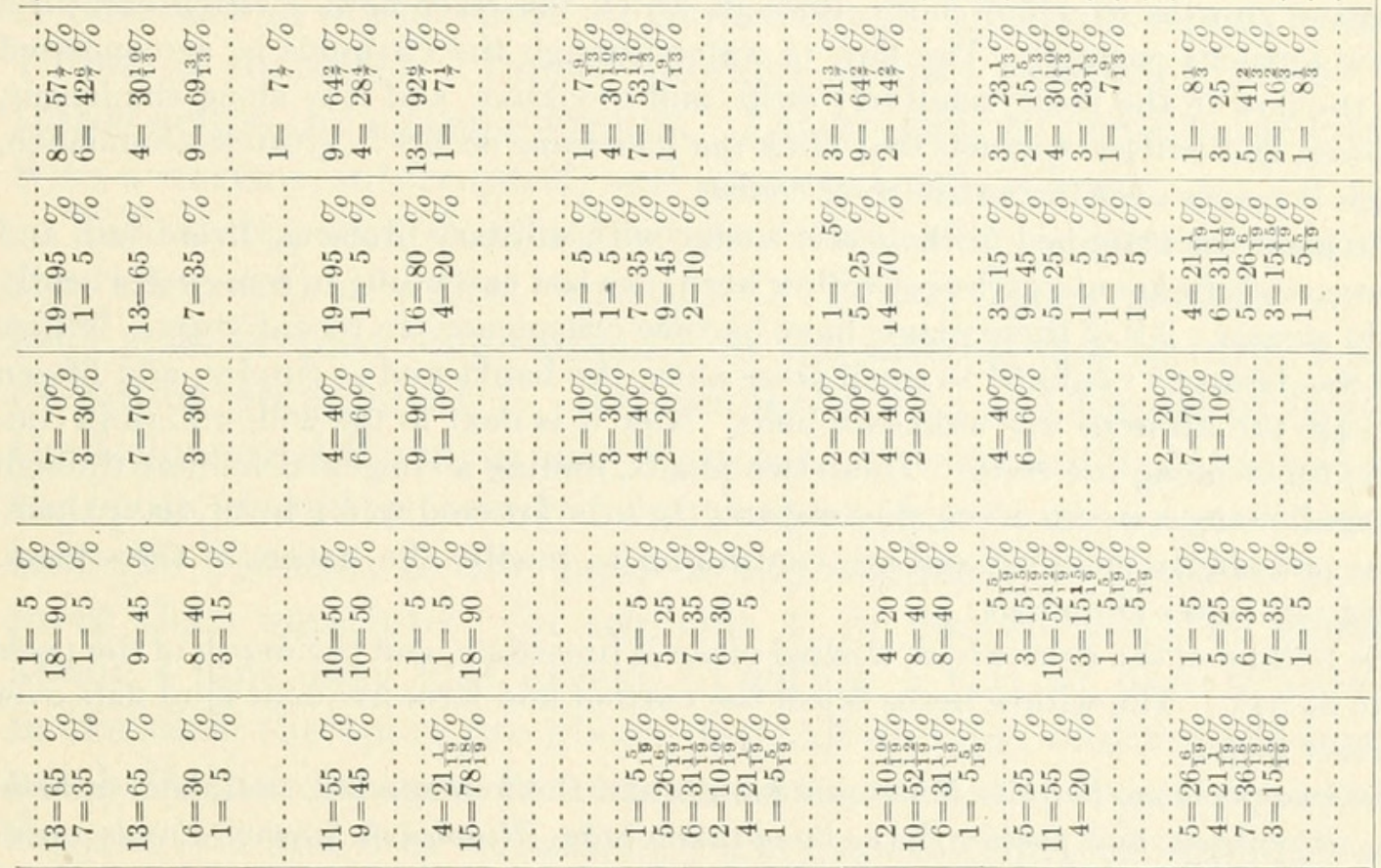

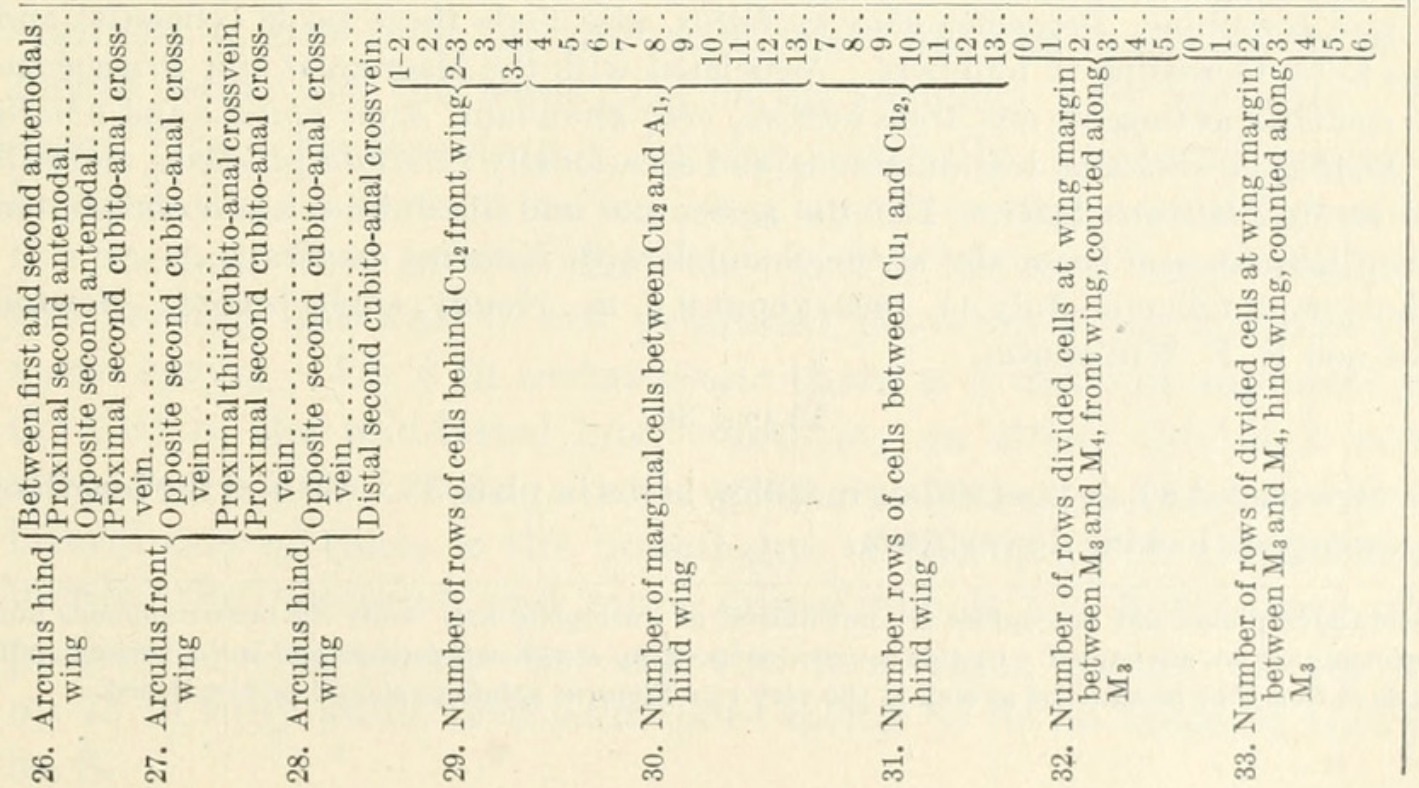


Notes.-The variation in the number of cubito-anal cross-veins in the front wing is in the region distal to the level of the arculus in every case but 1 wing of trniolata and 3 wings of wabashensis.

The curving of the first cubito-anal cross-veins with the convex side distal is constant and is most marked in the hind wing.

In one front wing of tæniolata there is a basal antenodal of the second series.

Every specimen studied has 3 cubito-anal cross-veins in the hind wings, excepting one wing of illinoiensis, which is evidently a freak.

\section{EXPLANATION OF PLATES.}

\section{Plate 35.}

View looking up the Wabash River, 3 miles above Bluffton, Indiana. Six-Mile Creek empties into the river just above the patch of willow herb (Epilobium augustifolium) in which man is standing. A short, narrow channel through the willow herb, which grows out from the river bank on either side, is shown. This channel connects two long pools, the lower of which is about 300 yards long, the upper about 150 yards. These pools are closed at their lower and upper ends, respectively, with dense and extensive growths of willow herb, through which the river flows in each case in a narrow tortuous channel. The flow of water through the channels is, as compared with the flow in the pools, relatively swift, and brooklike, and it is along the longer, narrower, and swifter channels that Hetærina americana occurs in greatest abundance, though it ranges over the entire river course.

The pools are margined at the water's edge with military hibiscus, lizard tail, and willows, with frequent patches of willow herb, the last extending in some cases nearly to mid stream. All of these plants have become conspicuous in recent years. Willow herb was formerly confined to small areas along the banks and at ripples, and fifteen years ago the hibiscus was unknown here. Now it is next to the willow herb in conspicuousness along the river. These two plants, finding a congenial habitat through profound changes in the river, due apparently to a lowered water level, have themselves profoundly modified and are continuing to modify the nature of the stream. Lizard tail is less abundant.

The bottom of the river where washed clean is limestone, and the depth of the pools is 3 to $3 \frac{1}{2}$ feet. The willow herbs break the current and form frequent mud flats over the river bed.

The two pools are favorite Macromia haunts and the four species, tæniolata, wabashensis, illinoiensis, and pacifica, have been taken here, illinoiensis, however, only once. The rare gomphine, Dromogomphus spoliatus, also finds these pools congenial and seems to be increasing in numbers. Associated with the Macromias and Dromogomphus spoliatus as imagoes are Argia putrida, very abundant, Argia apicalis and tibialis and Enallagma exsulans, less numerous, and occasionally Libellula pulchella, and still more rarely Plathemis lydia. ${ }^{a}$ But the agrionines and libellulines are cosmopolitan in their habitats and occur also at the channels with Hetærina americana.

Photograph taken on July 11, 1909, about 9 a. m., cloudy, slight breeze. Newton Miller and E. B. Williamson.

\section{Plate 36.}

Camera placed where man stands in willow herbs in plate 35. View of the length of the lower pool, looking downstream.

$a$ The above plants and dragonflies are not offered as a complete list. Only the more numerous and conspicuous species are named. In this connection possibly Perithemis domitia and worn belated individuals of Gomphus graslinellus as well as the very rare Stylurus spiniceps should be mentioned. 


\section{SUPPLEMENTARY NOTES.}

Since the foregoing manuscript was prepared more collecting has been done at Bluffton, Indiana, and the following material has been taken along the Wabash River:

\section{Macromia tæniolata. August 1, 1909, 1 male.}

Macromia wabashensis. July 25, August 1 and 5, 1909, 10 males, 1 female.

Macromia illinoiensis. July 30, 1909, 1 male.

Macromia pacifica. July 25 and 30, August 1, 5, and 8, 1909, 18 males, 1 female.

The association of the four above-named species along the Wabash River at Bluffton during 1909 is thus established.

Macromia wabashensis. Female.

Length of abdomen, $58 \mathrm{~mm}$; hind wing, $52 \mathrm{~mm}$.

Lateral and dorsal spots on frons distinct, all about equal, rounded, $1 \mathrm{~mm}$. in diameter. Dorsal thoracic stripes extending about twothirds across the mesepisternum. Latero-ventral metathoracic carina with a narrow, interrupted, and obscured yellow line.

Yellow ring on abdominal segment 2 narrowly interrupted dorsally, the interruption widest anteriorly. Dorsal spots present on 3-8, each spot divided longitudinally in the median line to form 2 spots, excepting on segment 7. As compared with the female of tæniolata the following differences may be noted: In segment 3, in wabashensis, the spots extend anteriorly from the transverse carina more than onehalf the distance to the base of the segment; in trniolata scarcely more than one-third. In segment 4, in wabashensis, the spots are about $4 \mathrm{~mm}$. long and extend to within $1 \mathrm{~mm}$. of base of segment; in tæniolata the spots are about one-half as long, and extend scarcely one-half the distance from transverse carina to base of segment. Segments 5 and 6 in wabashensis have spots relatively as large as on segment 4; tæniolata, in the same way, has the spots on these segments relatively the same size as on segment 4 of trniolata. Segment 7 in wabashensis not divided medianly, produced posteriorly beyond the transverse carina as a small triangle on either side of the median line; in tæniolata the spot is divided longitudinally in the median line and is not produced posteriorly beyond the transverse carina. On 8 in wabashensis there is a distinct subbasal spot, divided in the middorsal line, consisting on either side of 2 smaller spots, each about $1 \mathrm{~mm}$. in its greatest diameter; the anterior and lateral one of these is the homologue of the spots on the other segments, the posterior and more dorsal one is the homologue of the projection posteriorly beyond the transverse carina of the spot on 7 ; in fully adult tæniolata there seems to be no trace of this spot on 8 . 
Wings hyaline, with indistinct, indefinite and scattered fumose areas; scarcely a trace of faint basal brown. Costa yellow to the stigma; stigma black. Antenodals of front wing 18-19, hind wing 12 ; postnodals of front wing 10; hind wing 11; triangle of front wing free, of hind wing crossed on one side, free on the other; subtriangle of front wing crossed.

Vulver lamina a short median thickening of the posterior edge of the sternum, slightly folded into a trough; on either side of the median line at the posterior end of the sternum is a small, rounded, triangular projection about $0.25 \mathrm{~mm}$. long and twice as wide at its base, pale, slightly chitinized. These two projections very narrowly continuous basally in the median line.

Described from a recently killed specimen taken along the Wabash River, just above the mouth of Six Mile Creek, Bluffton, August 1, 1909. The spots on segment 8 have faded to black in drying. This type female is in the author's collection. 


\section{$2 \mathrm{BHL}$ Biodiversity Heritage Library}

Williamson, E.B. 1909. "The North American dragonflies (Odonata) of the genus Macromia." Proceedings of the United States National Museum 37(1710), 369-398. https://doi.org/10.5479/si.00963801.37-1710.369.

View This Item Online: https://www.biodiversitylibrary.org/item/53183

DOI: https://doi.org/10.5479/si.00963801.37-1710.369

Permalink: https://www.biodiversitylibrary.org/partpdf/51136

\section{Holding Institution}

Smithsonian Libraries

\section{Sponsored by}

Smithsonian

\section{Copyright \& Reuse}

Copyright Status: NOT_IN_COPYRIGHT

This document was created from content at the Biodiversity Heritage Library, the world's largest open access digital library for biodiversity literature and archives. Visit BHL at https://www.biodiversitylibrary.org. 